\title{
Characterizing persistent unburned islands within the Inland Northwest USA
}

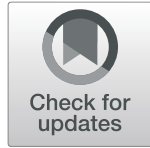

\author{
Anthony J. Martinez ${ }^{{ }^{*}}$ (D), Arjan J. H. Meddens ${ }^{1}$, Crystal A. Kolden ${ }^{1}$, Eva K. Strand ${ }^{1}$ and Andrew T. Hudak ${ }^{2}$
}

\begin{abstract}
Background: In the Inland Pacific Northwest of the United States, fire is a dominant driver of ecological change. Within wildfire perimeters, fire effects often vary considerably and typically include remnant patches of unburned islands. As fires reburn the landscape, some unburned islands remain persistently unburned. These persistent unburned islands can serve an important ecological function as fire refugia; however, their characteristics have not been quantified. The objective of this study was to assess the characteristics of persistent unburned islands and compare them to the burned areas that surround them. Using an existing database of unburned islands from 1984 to 2014, overlapping unburned islands were delineated. We sampled points in both persistent unburned islands and in areas burned by wildfire. At these sample points, we derived several topographical and other geospatial metrics, and we compared the characteristics of these groups. Because the study area covers many ecosystems, we stratified the analysis by different fire regime groups.

Results: Our analysis revealed that persistent unburned islands are not randomly distributed across the landscape. While the topography and vegetation fuel type that underlie persistent unburned islands differ from burned areas, these differences are dependent upon fire regime group and are less pronounced than what other studies have found. The topographic features that differed the most between persistent unburned islands and burned areas were terrain ruggedness, slope, and transformed aspect. We also found that, as unburned islands increased in persistence (i.e., remained unburned for an increasing number of overlapping fires), they decreased in size and shape complexity.

Conclusions: Our research shows that the biophysical setting underlying persistent unburned islands differs between forests and rangelands, and also differs from burned areas, which has potential applications for fire refugia prediction and management. Characterizing fire refugia and understanding the processes that contribute to their creation and maintenance will be important for land management as climate changes and increasingly large areas are affected by wildfire.
\end{abstract}

Keywords: fire refugia, persistence, remnant, topography, unburned area, wildfire

\footnotetext{
* Correspondence: ajmartinez@uidaho.edu

${ }^{1}$ College of Natural Resources, University of Idaho, 975 W 6th Street, Moscow,

Idaho 83844, USA

Full list of author information is available at the end of the article
} 


\section{Resumen}

Antecendetes: En las tierras centrales del noroeste de los Estados Unidos (Inland Pacific Northwest) el fuego es un conductor dominante de cambios ecológicos. Dentro de los perímetros donde hubo fuego, sus efectos varían frecuentemente e incluyen típicamente islas o parches no quemados. Cuando el fuego vuelve a quemar ese paisaje, algunas de estas islas persisten sin quemarse. Estas islas persistentes no quemadas pueden servir como una función ecológica actuando como refugios de fuego; no obstante, sus características no han sido cuantificadas. El objetivo de este estudio fue determinar las características de las islas persistentes y compararlas con las áreas quemadas circundantes. Usando una base existente de islas no quemadas desde 1984 a 2014, se delinearon superposiciones entre islas no quemadas. Muestreamos puntos en islas no quemadas y en áreas quemadas por incendios. En esos puntos de muestreo derivamos diferentes medidas topográficas y geoespaciales y comparamos las características de ambos grupos. Dado que el área de estudio cubre muchos ecosistemas, estratificamos el análisis en diferentes grupos de regímenes de fuegos.

Resultados: Nuestros análisis revelaron que las islas persistentes no quemadas no están distribuidas al azar en el paisaje. Aunque la topografía y el tipo de combustible vegetal superficial que caracteriza las áreas no quemadas difieren con el de áreas quemadas, estas diferencias son dependientes del grupo del régimen de fuego y es menos pronunciado que lo encontrado por otros estudios. Las características topográficas que mostraron las mayores diferencias entre islas quemadas y no quemadas fueron la rugosidad del terreno, la pendiente y la transformación de su aspecto. También encontramos que, cuando las áreas no quemadas aumentan en su persistencia (i.e., permanecieron no quemadas a pesar del incremento de fuegos superpuestos) decrecen en cambio en tamaño y la en la complejidad de su forma.

Conclusiones: Nuestro trabajo muestra que las características biofísicas encontradas en los combustibles superficiales en las islas que permanecen no quemadas difieren entre bosques y pastizales, y que también difieren de áreas quemadas, lo que implica una aplicación potencial para la predicción y refugio del fuego. La caracterización de los refugios contra el fuego y el entendimiento de los procesos que contribuyen a su creación y mantenimiento son importantes para el manejo de tierras mientras el clima cambia y se incrementan las áreas afectadas por incendios.

\section{Abbreviations}

CART: Classification and regression tree

CosAsp: Cosine of the aspect

$D$ : Kolmogorov-Smirnov test statistic

DP: Degree of persistence

ETM: Enhanced Thematic Mapper

FRAC: Fractal dimension index

FRG: Fire regime group

GAP: Gap Analysis Program

MTBS: Monitoring Trends in Burn Severity

NED: National Elevation Dataset

NNE: North-northeast

PDF: Probability density function

SSW: South-southwest

TM: Thematic Mapper

TPI: Topographic position index

TRASP: Transformed aspect

TRI: Terrain ruggedness index

TWI: Topographic Wetness Index

USGS: US Geological Survey

\section{Introduction}

The northwestern United States has experienced a considerable increase in fire activity due to anthropogenic climate change, largely due to summertime drying and warming conditions (Abatzoglou and Williams 2016). This trend is expected to continue, yielding increased frequency of megafires (Barbero et al. 2015). Such increases are worrisome, not only due to the greater potential for disasters and negative impacts to humans (Bowman et al. 2017), but also because changing fire regimes may have considerable cascading ecological consequences (Smith et al. 2016a). As such, there is great concern for a loss of forest resilience associated with these fires leading to land cover transitions and loss of biodiversity and ecosystem services (Vaillant et al. 2016; Stevens-Rumann et al. 2018); this is magnified for areas where repeat wildfires alter forest recovery trajectories (Stevens-Rumann and Morgan 2016). Within these repeat fire scars, however, there are unburned islands that, through multiple fires, have escaped or perhaps resisted burning. Persistent unburned islands may yield critical insights to restoring and maintaining forest resilience (Kolden et al. 2015a), but little is known about what makes them persistent, or about the attributes of such landscape features. In general, areas that function as refugia from fire continue to be under-analyzed in the ecological literature, despite the desire to manage 
ecosystems to support formation of such resilient features (Meddens et al. 2018b). This knowledge gap highlights a critical need that must be addressed to better understand fire interaction with ecosystems, particularly as climate change amplifies the effects of changing ecological disturbance regimes.

Fire regimes in the coniferous forests of the Pacific Northwest vary greatly in response to the top-down (e.g., steep climatic gradients associated with the complex topography of the region) and bottom-up controls (e.g., wide range of variation in local topography and vegetation types) (Gill and Taylor 2009). In biophysical settings that support cooler and moister forest types (i.e., higher elevation, northerly aspects), the fire regime is typified by lower frequency, higher intensity, stand-replacing fires; whereas forests that occur in warmer, drier settings (i.e., lower elevation, southerly aspects) are adapted to more frequent, lower intensity surface fires (Agee 1993). This general fire regime pattern was altered by anthropogenic factors over the past century. At lower elevations in particular, fire exclusion policies during the mid-twentieth century effectively lengthened fire return intervals relative to the historical norm, thus accumulating fuels to induce more stand-replacing fires (Rollins et al. 2001; Morgan et al. 2008; Morgan et al. 2017). A warming and drying climate and longer fire seasons since the latter twentieth century (Higuera et al. 2015) have been exacerbating the size of fires and area burned in the western USA, and these trends are forecasted to continue (Littell et al. 2009; Westerling 2016).

Fire frequency and its inverse, fire return interval, are important fire regime attributes for characterizing burn area and reburn dynamics. An increase in fire activity and area burned during the past century has fueled research related to how often areas burn in repeated fires and how historical fires impact subsequent fires (Harvey et al. 2016; Stevens-Rumann and Morgan 2016; Stevens-Rumann et al. 2016; Prichard et al. 2017). Research in the northern Rocky Mountain forests supports the hypothesis that burn severity is lower in wildfires burning in relatively short succession $(<10$ years) following a previous fire (Harvey et al. 2016). Stevens-Rumann and Morgan (2016) found that lower severity levels in subsequent fires could be observed for as long as three decades in mixed conifer forests, and Morgan et al. (2017) found evidence for such legacy fire effects persisting for decades longer in higher elevation forests. Because the legacy of fires can alter the consequences of subsequent fires and may even serve as a barrier to fire spread (Prichard et al. 2017), legacy fire perimeters have been suggested as useful in fire suppression tactics (Stevens-Rumann and Morgan 2016). In other ecosystems, areas that have reburned exhibit greater burn severity (van Wagtendonk et al. 2012) due to the accumulation of fuels and conversion to a different fuel type. This emphasizes the need for further study of reburns and their associated effects on organisms and ecosystem processes (Prichard et al. 2017). At the landscape scale, quantifying reburns, fire return interval, and time between individual subsequent wildfires is commonly estimated from spatial fire atlas data (e.g., Eidenshink et al. 2007; Gibson et al. 2014) by overlaying historical fire perimeters to determine the number of times an area has burned or the time between subsequent fires. A shortcoming of spatial fire perimeter data is their inability to provide information about unburned areas within the fire perimeter (Kolden and Weisberg 2007; Kolden et al. 2015b). Advances in remote sensing of wildfire heterogeneity, however, have improved detection of fire edges (e.g., Smith et al. 2016b), facilitating studies to accurately delineate unburned islands over large areas (Meddens et al. 2016).

Recent research has focused on quantifying the unburned area within fire perimeters (Kolden et al. 2012; Meddens et al. 2016), and both characterizing these islands across space and time (Meddens et al. 2018a) and determining predictors of fire refugia formation (Krawchuk et al. 2016). One of the limits of such studies, however, is that the formation of unburned islands is a function of both relatively static and highly dynamic environmental conditions. While topography and geomorphology remain relatively static over decades to centuries, fuels fluctuate considerably in both structure and mass over the same period. Similarly, fuels vary little on an annual temporal scale, but weather and climate are highly dynamic over comparatively short periods, from hours to months. These factors all contribute to the formation of both ephemeral (single-event) and persistent (multiple-event) unburned islands and fire refugia (Meddens et al. 2018b). For example, some unburned islands form due to persistently wet topographic depressions (Krawchuk et al. 2016), while others form where vegetation has not yet matured enough to become fuel. In one study, fire refugia from a prior event burned more severely than the surrounding vegetation in a subsequent fire due to fuel maturity (Kolden et al. 2017), while Kolden et al. (2015a) highlighted the geographic differences between unburned islands associated with antecedent versus coincident climatic conditions (e.g., winter snowpack supporting vegetation growth versus summer drought making it available to burn). Further complicating attempts to identify drivers of unburned island formation is the role of fire management; some islands have formed entirely because humans used wildfire suppression actions or fuel breaks to prevent advancement and consumption (Kolden and Abatzoglou 2018). As such, studies assessing formation of ephemeral refugia following a single fire event are less conclusive. Thus, there is a critical gap in identifying the factors that contribute to formation of persistent unburned islands and fire refugia through multiple wildfires across regions. Kolden et al. (2017) found that prior fire refugia failed to 
persist through a 2012 wildfire, and their limited study of a single fire is the only one to date to assess refugia persistence through multiple fire events. The unburned island database developed by Meddens et al. (2018a) provides an opportunity to fill this knowledge gap.

Our objectives in this study were to (1) compare the patch metrics of persistent unburned islands (i.e., unburned landscape patches that have remained unburned through at least two fires) to areas that were classified as unburned only once, (2) explore the spatial and temporal characteristics of overlapping fires and their persistent unburned areas, and (3) evaluate differences in landscape characteristics (e.g., topography, land cover type, fuel type) between persistent unburned areas and areas that were burned at least once over the study period (1984 to 2014).

\section{Methods}

\section{Study area}

The study area was located within the Inland Pacific Northwest of the USA, including Washington and Oregon east of the Cascade Crest and Idaho (Fig. 1). Because this study made use of their unburned island database, the extent matches that of Meddens et al. (2018a). The study area (approximately $499200 \mathrm{~km}^{2}$ ) was covered by $35 \%$ forest, $42 \%$ rangeland (including grassland, shrubland, and semi-desert), with the remaining $23 \%$ including water, agriculture, and urban development (US Geological Survey 2011). The high elevations in the west (Cascade Mountains) and the east (Rocky Mountains) of the study area were predominantly covered with subalpine fir (Abies lasiocarpa [Hook.] Nutt.) and Engelmann spruce (Picea engelmannii Parry ex Engelm.) forests, whereas the middle elevations were primarily covered with mixed-conifer forests, transitioning to ponderosa pine (Pinus ponderosa Lawson \& C. Lawson) forest at lower elevations. The Columbia Basin, in the middle of the study area, was primarily rangeland (including grass- and shrub-dominated areas) and included a substantial amount of agricultural lands (Franklin and Dyrness 1973). From 1984 to $2014,16.5 \%$ of the study area had burned at least once, and $9.9 \%$ of the total area remained unburned within fire perimeters through at least one fire.

\section{Datasets}

The datasets used for this study included a recently developed unburned island database (Meddens et al. 2018a), a Landsat-based land cover type dataset (US Geological Survey 2011), topographical indices derived from a digital elevation model, and fire regime groups (FRG; Barrett et al. 2010; LANDFIRE 2011a; see Fig. 1b) and fuel models (Anderson 1982; LANDFIRE 2011b) acquired from LANDFIRE. All raster datasets used in this analysis were $30 \mathrm{~m}$ resolution products. Meddens

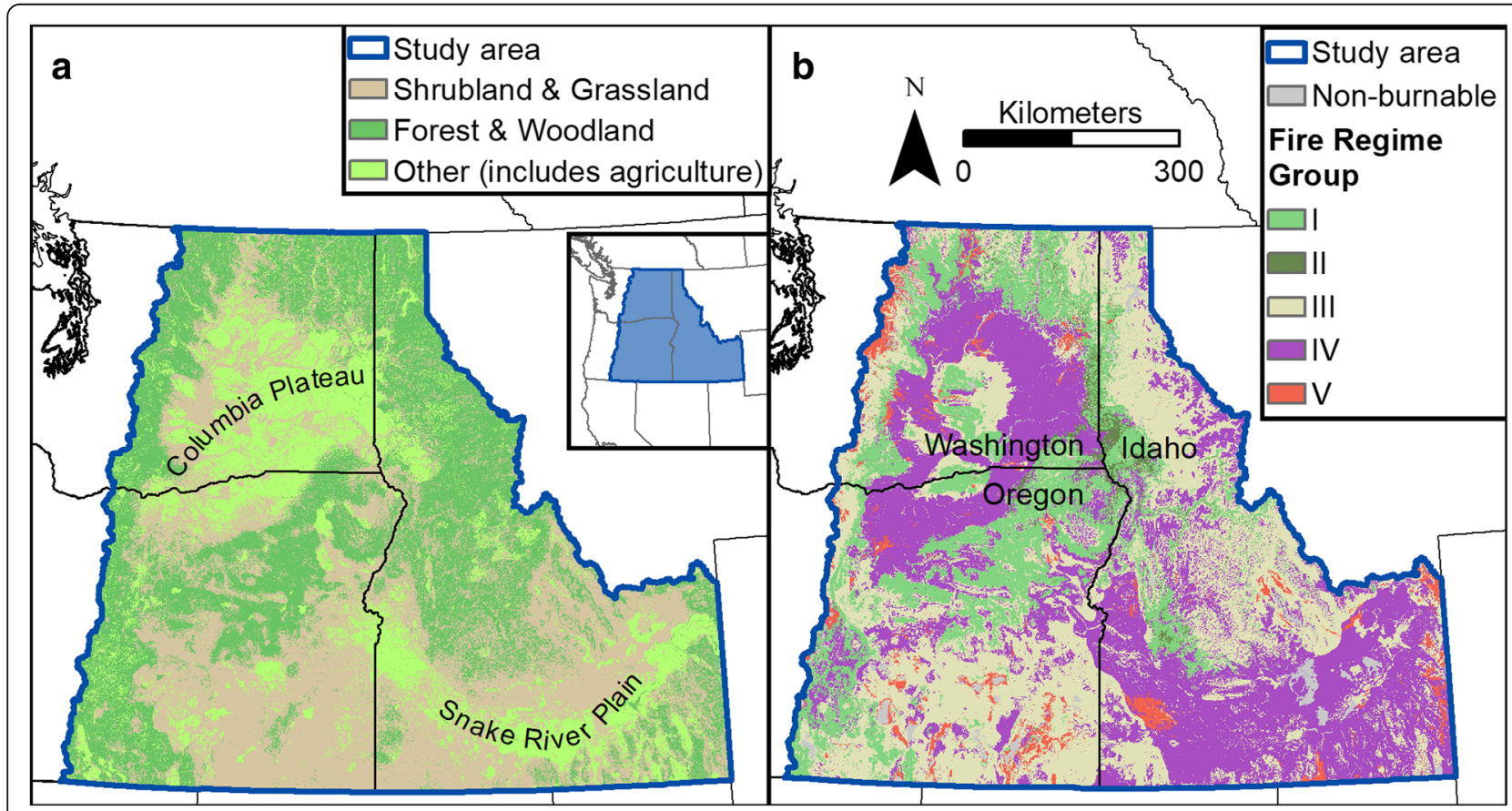

Fig. 1 The study area, encompassing the Inland Northwest. The inset map shows the study area location within the western United States. (a) Landcover was aggregated from the USGS GAP landcover data (30 m resolution). (b) Fire regime groups (FRGs) across the study area. Note: the Snake River Plains and Columbia Plateau are predominantly agricultural lands, so their fire regime groups are uncertain and may change over time 
et al. (2018a) developed a database of unburned islands for the Inland Pacific Northwest for fires from 1984 to 2014 using classification trees (CART; Breiman et al. 1984) and spectral vegetation indices derived from Landsat data. They used fire perimeters obtained from Monitoring Trends in Burn Severity (MTBS; Eidenshink et al. 2007), which records wildland fires $>404$ ha (1000 acres). While MTBS fire perimeter polygons were used, the classification of burned and unburned pixels by Meddens et al. (2018a) for their database was completed following methods described in Meddens et al. (2016) and did not utilize the MTBS burn severity raster data. Unburned islands were detected with a minimum size threshold of two Landsat pixels (0.18 ha). Their algorithm identified 701188 unburned islands within 2318 fires (including 100 prescribed fires) with an overall accuracy of a subset of fires of $89 \%$ (Meddens et al. 2016).

Land cover data were classified from the USGS GAP land cover analysis dataset (US Geological Survey 2011). The GAP land cover classifications were determined using Landsat Thematic Mapper (TM) and Enhanced Thematic Mapper (ETM) acquisitions.

To calculate the topographical indices (Table 1), we used the $30 \mathrm{~m}$ resolution National Elevation Dataset (NED; US Geological Survey 2016).

The Topographic Position Index (TPI; Weiss 2001; De Reu et al. 2013) identifies where, topographically, each raster cell exists by comparing the elevation of each cell with the mean elevation of the surrounding cells. A TPI $\approx 0$ indicates a constant or near-constant slope, which includes flat areas, mid-slopes, and saddles. TPI $>0$ indicate ridges and upper slopes, and TPI $<0$ indicate valleys and lower slopes. The TWI (Topographic Wetness Index; Beven and Kirkby 1979; McKenzie and Ryan 1999) is an indicator of soil and water movement and has been shown to be highly correlated to soil moisture. Greater TWI indicates more runoff and less water accumulation, while lower TWI values indicate less runoff and more water accumulation.
The Terrain Ruggedness Index (TRI; Riley et al. 1999) identifies the degree of topographic ruggedness by comparing the mean of the absolute differences between the elevation of each cell and that of the surrounding cells. Greater TRI indicates greater topographic ruggedness. TPI and TRI were calculated with a seven by seven focal window, $90 \mathrm{~m}$ in each direction. For these indices, focal frames had third order queen contiguity including all diagonals (Additional file 1). Two aspect-derived indices were used to explore the aspect of the persistent unburned islands: the cosine of the aspect (Additional file 2) and the transformed aspect (TRASP; Roberts and Cooper 1989). While the cosine of the aspect was considered for analysis, TRASP was used as the primary aspect-derived index for visualization. This aspect transformation, a gradient from north-northeast (generally the coolest and wettest orientation in the study area) to south-southwest (generally the hottest and driest), is an indicator of solar radiation and localized climate (Moisen and Frescino 2002; Hudak et al. 2008).

Note that these datasets have certain characteristics associated with them that limited our analysis. The unburned islands database and all raster datasets (including the fuel model data) have a $30 \mathrm{~m}$ spatial resolution that masks fine-scale variability. Fire perimeter mapping is subjective, frequently resulting in mapping error (Kolden and Weisberg 2007), including numerous surface conditions in which remotely sensed data would incorrectly identify unburned areas (Kolden et al. 2012). Further, delimiting unburned islands using spectral reflectance data resulted in an $11 \%$ error rate (Meddens et al. 2016).

\section{Data analysis}

The areas where unburned islands overlapped across multiple fires were identified as persistent fire refugia. After converting the unburned island database (Meddens et al. 2018a) to a shapefile, the unburned polygons were overlaid in a geographic information system (GIS), and any overlapping areas were converted into unique polygons (see Fig.

Table 1 Definitions for the shape and topographic indices used to characterize unburned islands within fires in the Inland Pacific Northwest from 1984 to 2014. $p_{\mathrm{ij}}=$ perimeter $(\mathrm{m})$ of patch $\mathrm{ij} . a_{\mathrm{ij}}=$ area $\left(\mathrm{m}^{2}\right)$ of patch $\mathrm{ij}$. TPI and TRI were calculated with a seven by seven focal window (90 $\mathrm{m}$ in each direction). Aspect is azimuth in degrees

\begin{tabular}{|c|c|c|c|c|}
\hline Index & Abbreviation & Formula & Notes & Reference \\
\hline Fractal Dimension Index & FRAC & $\frac{2 \ln \left(0.25 p_{\mathrm{ij}}\right)}{\ln \left(a_{\mathrm{ij}}\right)}$ & Shape complexity, from less complex to more complex & McGarigal and Marks 1995 \\
\hline Topographic Position Index & TPI & \multicolumn{2}{|c|}{$\begin{array}{l}\text { Difference between the value of a cell and the mean elevation of the } \\
\text { surrounding cells }\end{array}$} & Weiss 2001 \\
\hline Topographic Wetness Index & TWI & In $\frac{\text { upslope drainage }}{\tan (\text { slope })}$ & Measure of hydrologic pooling potential & Beven and Kirkby 1979 \\
\hline Terrain Ruggedness Index & TRI & \multicolumn{2}{|c|}{$\begin{array}{l}\text { Mean of the absolute differences between the elevation of a cell and } \\
\text { the elevation of the surrounding cells }\end{array}$} & Riley et al. 1999 \\
\hline Slope & Slope & Slope in degrees & Steepness & \\
\hline Cosine of the aspect & CosAsp & $\cos ($ Aspect $)$ & Gradient from north to south aspects & \\
\hline Transformed aspect & TRASP & $\frac{-\cos (\text { Aspect }-30)+1}{2}$ & Gradient from northeastern to southwestern aspects & Roberts and Cooper 1989 \\
\hline
\end{tabular}


2). The degree of persistence (DP, the number of fires through which an unburned island has remain unburned) was then assigned to each of these overlapping areas. We assumed that the status of each $900 \mathrm{~m}^{2}$ Landsat pixel was either unburned or burned, and the status of the pixel was uniform across the pixel.

\section{Patch metrics}

To assess the patch metrics of individual unburned areas, we extracted two unburned patch metrics for each unburned patch within the database: patch area $\left(\mathrm{m}^{2}\right)$ and Fractal Dimension Index (FRAC; McGarigal and Marks 1995). FRAC has a range from one to two; as FRAC approaches two, patches have perimeters that become highly convoluted; as FRAC approaches one, patches become simpler (more round or square). The distributions of unburned island areas for each DP were compared to one another in a series of two-sample Kolmogorov-Smirnov tests. This test reports the maximum difference between the two cumulative density distributions $(D)$. It can detect differences in medians, variances, and distributions (Corder 2014). This allowed us to assess if there were truly differences in the areas of unburned islands as they remain unburned for additional fires. These tests were repeated on the FRAC data to asses if there were also differences in patch shape complexity as islands remained unburned over additional fires.

For each patch shape characteristic, kernel density estimations were plotted along with the median value for

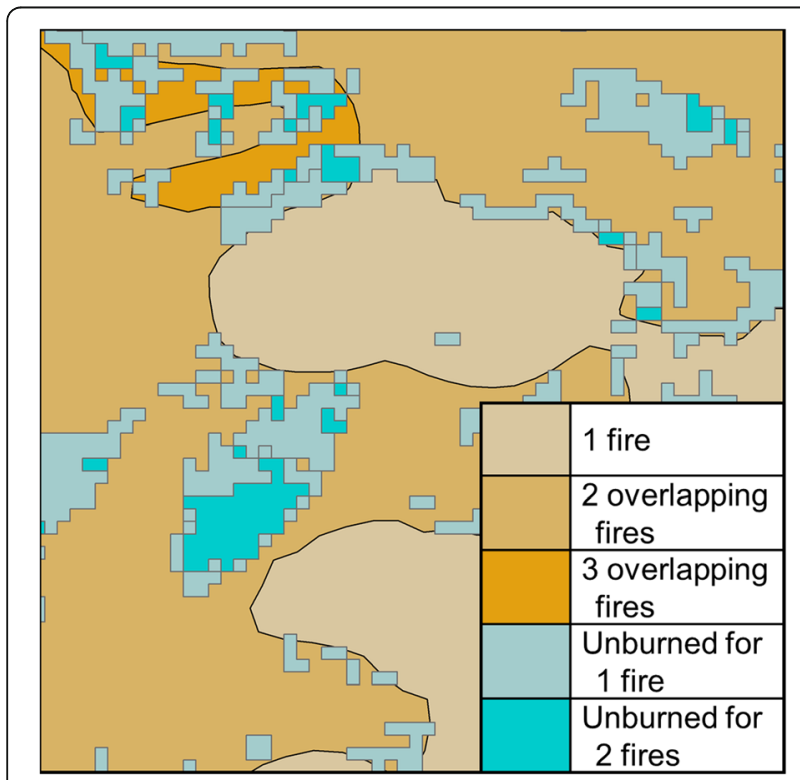

Fig. 2 Conceptual diagram of calculations used to determine the degree of persistence (DP) of unburned islands within fires in the Inland Pacific Northwest from 1984 to 2014. Fire perimeters are shown in semitransparent brown, unburned islands shown in semi-transparent cyan. The degree of persistence, the number of fires a patch has remained unburned, is labeled on each unburned island patch visualization. Kernel density estimation is a nonparametric method of estimating the probability density function (PDF) of a given variable (Hollander et al. 2014). When integrated over a given range, the area under the PDF curve is the probability within the specified range (Shynk 2012). They are useful for visualizing the distribution of these data and have the advantage over histograms of showing a continuous probability density estimate, whereas histograms jump from bin to bin (Hollander et al. 2014). The median was selected over the arithmetic mean to show central tendency because many of these datasets are highly right-skewed with extreme outliers and heavy tails.

\section{Spatial patterns}

To identify the locations that were subject to heightened fire activity (i.e., reburning) and increased proportions of (persistent) unburned areas, we calculated the proportion of area covered by fire perimeters and unburned islands for all fire perimeters and unburned islands in the database. These proportions were summarized within $6 \mathrm{~km} \times$ $6 \mathrm{~km}$ grid cells. We presented the proportion of area burned at least once and the proportion of area burned at least twice (i.e., reburned). Likewise, we presented the proportion of area of both unburned islands and persistent unburned islands. By intersecting the yearly MTBS wildfire polygons and the yearly unburned island polygons, we calculated the degree of overlap for both fire perimeters and unburned areas (Eidenshink et al. 2007). The proportion of area burned was determined by summing the total area within fire perimeters and dividing it by the area of each $6 \mathrm{~km} \times 6 \mathrm{~km}$ grid cell $\left(36 \mathrm{~km}^{2}\right)$. The same process was used to determine the proportion of area burned at least twice, except that areas that were burned only once were removed from the analysis. The process was repeated for unburned islands (unburned $\geq 1$ time) and persistent unburned islands (unburned $\geq 2$ times).

To assess whether the spatial distributions of overlapping fire perimeters and unburned islands were randomly distributed or showed some degree of spatial co-occurrence, we calculated the observed versus the expected fire perimeter and unburned island areas. The observed fire perimeter areas were calculated by summing the fire perimeter area for each patch by the degree of reburn and the number of fires that had burned over an area previously burned. The expected reburn area ( ReburnArea) was estimated using the equation:

$$
\text { ReburnArea } \mathrm{t}_{\mathrm{t}}=\text { TotFireArea } \times\left(P_{\text {reburn }}\right)^{\mathrm{t}}
$$

where $t$ is degree of reburn (the number of times a patch has reburned), $P_{\text {reburn }}$ is the proportion of area that reburned once, and TotFireArea is the total area burned within the entire dataset $\left(8223980 \mathrm{~km}^{2}\right) . P_{\text {reburn }}$ was 
calculated by dividing the total area reburned by the total area within fire perimeters (0.195). Absent from any spatial influences, we assumed that the proportion of area that burned would remain constant, so that $19.5 \%$ of the area reburned would reburn again, and so on.

The same process was used to calculate observed and expected areas of unburned islands by their degree of persistence, the number of fires during which each patch has remained unburned. The expected unburned area (Unb $\widehat{u r n}$ Area) was estimated using the equation:

$$
\text { UnburnArea }{ }_{\mathrm{q}}=\text { TotFireArea } \times\left(P_{\text {unburn }}\right)^{\mathrm{q}}
$$

where $q$ is the degree of persistence (the number of fires through which each patch has remained unburned), $P_{\text {unburn }}$ is the proportion of area with fire perimeters that remained unburned, and TotFireArea is the total area burned within the entire dataset (8223 $980 \mathrm{~km}^{2}$ ). $P_{\text {unburn }}$ was calculated by dividing the total area of unburned islands ( $\mathrm{DP} \geq 1$ ) by the total area within fire perimeters (0.099). Absent from any external influences, we would expect that the proportion of area that burns will remain constant, so that $9.9 \%$ of the area unburned will not be burned again, and so on. We then compared both the expected reburn area and the unburned area by degree of reburn or persistence with the observed areas within the database.

\section{Vegetation characteristics}

To assess the difference in vegetation composition of persistent unburned islands and burned area, the frequency of each of the 13 fuel types was compared between burned and persistent unburned areas by sampling 51704 pixels, half from burned areas, half from persistent unburned islands $\left(n=51704 ; n_{1}=n_{2}=25\right.$
852). We used the 13 Anderson Fire Behavior Fuel Models (Anderson 1982) to classify vegetation fuel types. This model was chosen over other models, such as the 40 Scott and Burgan Fire Behavior Fuel Models (Scott and Burgan 2005), for two reasons: (1) with only 13 fuel types, it simplified comparison and interpretation; and (2) the added precision of additional fuel models becomes unnecessary when identifying patterns at such a coarse scale and within broad groups, such as the five FRGs (fire regime groups I through V). To determine whether the fuel type was dependent or independent of the burn status, Pearson's chi-squared test for independence using equal sample sizes $\left(n_{1}=n_{2}=25852\right)$ was applied.

\section{Topographic characteristics}

To compare the underlying topography of persistent unburned islands and areas that burned within fire perimeters, seven topographic indices were investigated (Table 1). For the topographic analysis, 60000 pixels were sampled; 30000 each from burned areas and persistent unburned islands. The data were stratified by the FRG (Table 2) to parse out differences in unburned islands between vegetation types with similar fire regimes. For each index, the kernel density estimations were plotted along with the median value. Two-sample KolmogorovSmirnov tests were calculated to investigate the differences in frequency distributions between persistent unburned and burned pixels.

\section{Results}

Across all 2318 fires, there were up to seven overlapping fires (reburned six times), which resulted in areas that were unburned up to four times ( $\max \mathrm{DP}=4$; Fig. 3 ). Of the total fire area within the fire perimeter $\left(8223980 \mathrm{~km}^{2}\right)$, $15.1 \%$ of the area reburned and $9.9 \%$ was unburned. Of the unburned area, 97\% remained unburned through one fire

Table 2 Fire regime groups (FRG) used in characterizing unburned islands within fires in the Inland Pacific Northwest from 1984 to 2014. Adapted from Malesky et al. 2018

\begin{tabular}{|c|c|c|c|c|}
\hline $\begin{array}{l}\text { Fire regime } \\
\text { group }\end{array}$ & $\begin{array}{l}\text { Frequency } \\
\text { (yr) }\end{array}$ & Severity & Severity description & $\begin{array}{l}\text { Example cover type from } \\
\text { study area }\end{array}$ \\
\hline I & 0 to 35 & Low or mixed & $\begin{array}{l}\text { Generally low-severity fires replacing less than } 25 \% \text { of the dominant } \\
\text { overstory vegetation; can include mixed-severity fires that replace up } \\
\text { to } 75 \% \text { of the overstory (typical of perennial grasslands) }\end{array}$ & $\begin{array}{l}\text { Ponderosa pine; dry mixed } \\
\text { conifer forest }\end{array}$ \\
\hline$\|$ & 0 to 35 & Replacement & $\begin{array}{l}\text { High-severity fires replacing greater than } 5 \% \text { of the dominant overstory } \\
\text { vegetation (annual grasslands and some forests with frequent surface fires) }\end{array}$ & Grassland \\
\hline III & 35 to 200 & Mixed or low & $\begin{array}{l}\text { Generally mixed severity; can also include low-severity fires (many forests } \\
\text { and shrublands) }\end{array}$ & $\begin{array}{l}\text { Big sagebrush }{ }^{a} \text {, lodgepole } \\
\text { pine }^{b}\end{array}$ \\
\hline IV & 35 to 200 & Replacement & High-severity fires (forests and shrublands) & $\begin{array}{l}\text { Big sagebrush, lodgepole } \\
\text { pine }\end{array}$ \\
\hline V & $\geq 200$ & $\begin{array}{l}\text { Replacement or } \\
\text { any severity }\end{array}$ & $\begin{array}{l}\text { Generally, replacement severity; can include any severity type in this } \\
\text { frequency range (some moist forests, tundra, and deserts) }\end{array}$ & $\begin{array}{l}\text { Very sparse big sagebrush } \\
\text { steppe; spruce-fir forest }\end{array}$ \\
\hline
\end{tabular}

artemisia tridentata Nutt.)

b(Pinus contorta Douglas ex Loudon) 


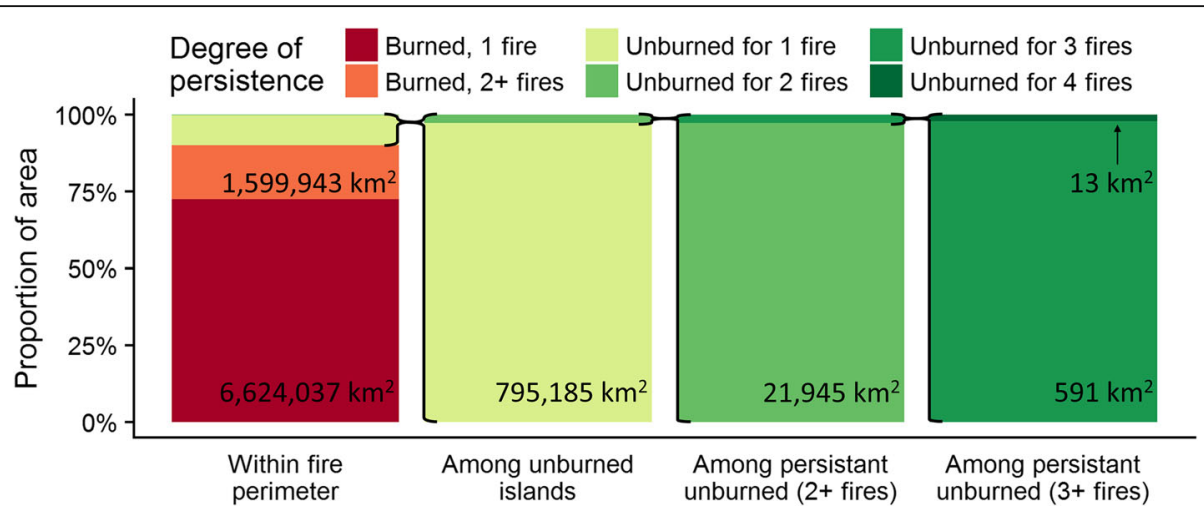

Fig. 3 The distribution of unburned islands (area) within fires in the Inland Pacific Northwest from 1984 to 2014 by the degree of persistence. The proportional area decreases exponentially with each additional fire through which an island remains unburned

event, $2.7 \%$ through two fire events, $0.1 \%$ through three fire events, and $<0.01 \%$ through four fire events (Fig. 3).

\section{Patch metrics}

Patch area of unburned islands decreased with each additional fire (i.e., as the DP increased; Fig. 4a; Table 3). The median patch area of unburned islands decreased by $33 \%$ from one to two fires $(D=0.3570, P<0.001)$, and $50 \%$ from two to three fires $(D=0.1357, P<0.001)$.
There was no significant difference in patch area from three to four fires $(D=0.1202, P=0.1748)$.

With each successive fire that a patch remained unburned, the patch shape became rounder and simpler (Fig. 4b). The median FRAC decreased by 0.02 from one to two fires $(D=0.3533, P<0.001)$, and by 0.01 from two to three fires $(D=0.1324, P<0.001)$. There was no significant difference in patch shape complexity distribution from three to four fires $(D=0.1166, P=0.2018)$.

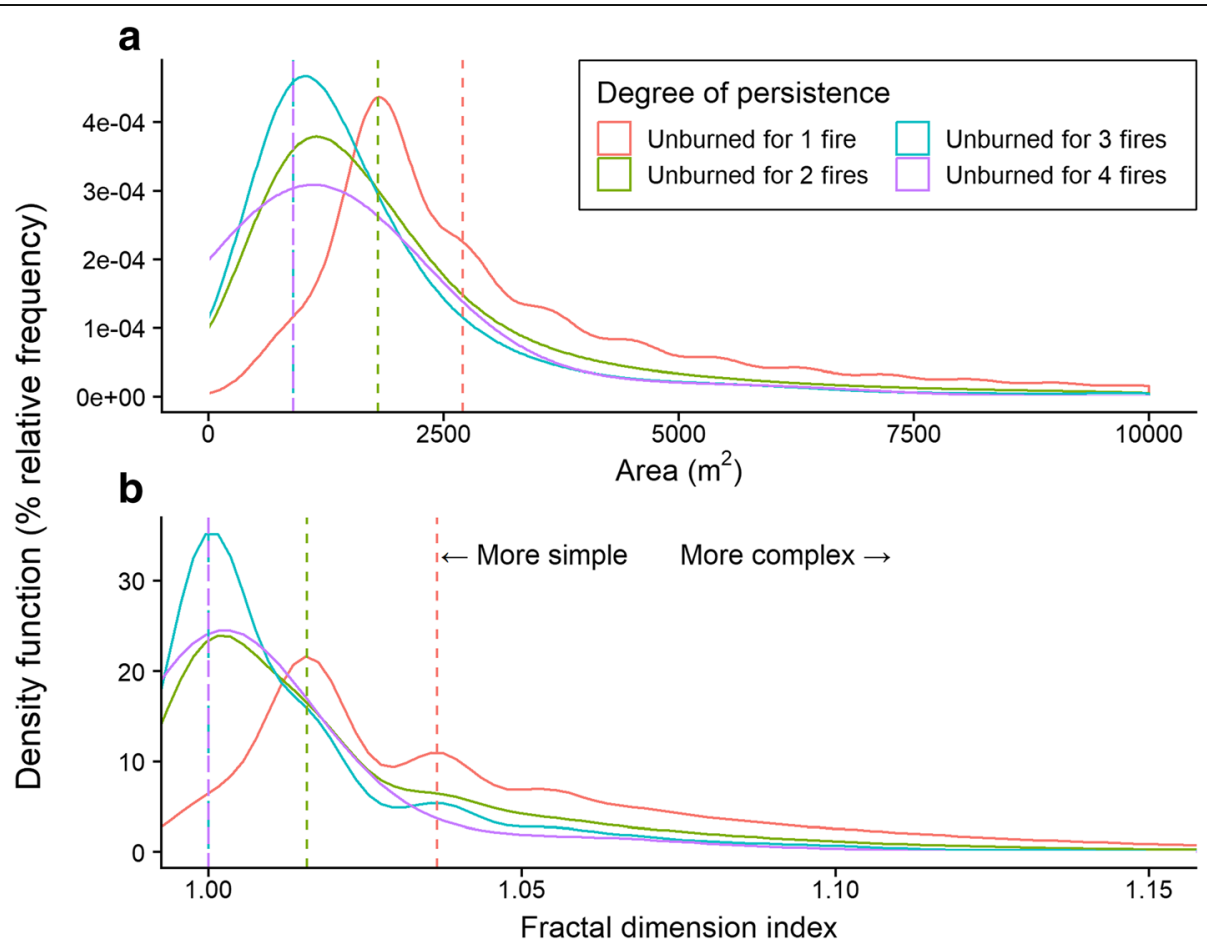

Fig. 4 The distribution of shape characteristics by the degree of persistence of unburned islands within fires in the Inland Pacific Northwest from 1984 to 2014. The median value is shown with a dashed line of the same color. (a) The patch size (area) decreases as the degree of persistence (DP) increases until $D P=4$, which has the same area as unburned islands with DP $=3$. (b) The fractal dimension index is a measure of shape complexity: higher values indicate more complex shapes; lower values indicate more simple shapes (round or square). With each successive fire through which an island remains unburned, the island becomes rounder and simpler until DP $=4$, which has the same FRAC as DP $=3$ 
Table 3 Two-sample Kolmogorov-Smirnov D statistic and P-values to test significance of difference between the and Fractal Dimension Index (FRAC) distributions among unburned islands within fires in the Inland Pacific Northwest from 1984 to 2014 based on their degree of persistence

\begin{tabular}{|c|c|c|c|c|c|}
\hline \multirow{2}{*}{$\begin{array}{l}\text { Degree of } \\
\text { persistence }\end{array}$} & \multicolumn{2}{|l|}{ Area } & \multicolumn{2}{|l|}{ FRAC } & \multirow{2}{*}{$\begin{array}{l}\text { Number of } \\
\text { observations }\end{array}$} \\
\hline & $\bar{D}$ & $P$ & $\bar{D}$ & $P$ & \\
\hline 1 vs. 2 & 0.357 & $<0.001$ & 0.3533 & $<0.001$ & $\begin{array}{l}n_{1}=749179 \\
n_{2}=64765\end{array}$ \\
\hline 1 vs. 3 & 0.4927 & $<0.001$ & 0.4857 & $<0.001$ & $\begin{array}{l}n_{1}=749179 \\
n_{3}=2771\end{array}$ \\
\hline 1 vs. 4 & 0.6129 & $<0.001$ & 0.6023 & $<0.001$ & $\begin{array}{l}n_{1}=749179 \\
n_{4}=87\end{array}$ \\
\hline 2 vs. 3 & 0.1357 & $<0.001$ & 0.1324 & $<0.001$ & $\begin{array}{l}n_{2}=64765 \\
n_{3}=2771\end{array}$ \\
\hline 2 vs. 4 & 0.2559 & $<0.001$ & 0.249 & $<0.001$ & $\begin{array}{l}n_{2}=64765 \\
n_{4}=87\end{array}$ \\
\hline 3 vs. 4 & $0.1202^{*}$ & $0.1748^{*}$ & $0.1166^{*}$ & $0.2018^{*}$ & $\begin{array}{l}n_{3}=2771 \\
n_{4}=87\end{array}$ \\
\hline
\end{tabular}

*Indicates $P>0.05$

\section{Spatial patterns}

The highest density of fire events and areas burned through at least two fire events occurred near the intersection of Owyhee and Twin Falls counties in southwestern Idaho (Fig. 5a and b). This area is classified as the Owyhee Uplands section of the Intermountain Semidesert ecosystem province (Bailey 2016). The highest densities of unburned islands occurred in patches throughout this region (Fig. 5c), and persistent unburned islands appeared in the highest densities in areas of high unburned islands (Fig. 5c and d).

After estimating the overall change in reburning $\left(P_{\text {reburn }}=0.1945\right.$; i.e., $19.5 \%$ of burned area burning again), the area that actually reburned according to our database was higher than expected for all degrees of reburn other than those reburned once (Fig. 6a and c). There was $14 \%$ more area reburned than expected for areas being reburned twice; $40 \%$ for three times; $47 \%$ for four times; $55 \%$ for five times; and 5\% for six times, indicating that areas that had already burned were more likely to burn again.

The chance of an area being unburned within a given fire perimeter was $9.9 \%$ (or $P_{\text {unburn }}=0.099$ ); the area of persistent unburned islands was lower than expected (Fig. $6 \mathrm{~b}$ and d). There was $72 \%$ less persistently unburned area within fire perimeters for areas remaining unburned for two fires; $93 \%$ for three fires; and 98\% for four fires, indicating that areas that had been unburned were more likely to burn than to remain unburned in a subsequent fire.

\section{Vegetation characteristics}

There were significant differences between burned versus persistent unburned areas by fuel type $\left(\chi^{2}=1323.3\right.$, df $=12, P<0.001$; Fig. 7). Generally, persistent unburned islands were more likely to be found in fuel-limited areas, such as in grass-dominated vegetation types, and were less likely to be found in areas that were fuel abundant, such as in heavy brush and forests.

\section{Topographic characteristics}

In FRGs I to IV (Table 2), persistent unburned islands were more likely than burned areas to be located at the foot of slopes and valleys (Table $4 ; P<0.0001$ for FRG I to IV). In FRG $\mathrm{V}$, persistent unburned islands were slightly more likely to be found on slope shoulders and ridges $(P=0.0035)$. The greatest difference in median TPI between persistent unburned islands and burned areas was in FRG II, which includes annual grasses and dry ponderosa pine forests (Fig. 8).

Similarly, persistent unburned islands were more likely to be found in areas with lower runoff and a higher likelihood of water accumulation than in burned areas in FRGs I, II, and IV (Table 4; $P<$ 0.0001), while persistent unburned islands were more likely to be found in areas of higher runoff in FRG V $(P=0.0082$; Fig. 9$)$. There was no significant difference in the distributions of TWI values for persistent unburned islands and burned areas for FRG II $(P=$ 0.1234).

Persistent unburned islands were more likely to be found in more rugged areas for FRGs I and II (high frequency fire regimes; $P<0.0001$ ), while they were more likely to be found in less rugged areas in FRGs III and IV (low frequency fire regimes; $P<0.0001$ ). There was no significant difference between the distributions in FRG V (Fig. 10; $P=0.0736$ ). 


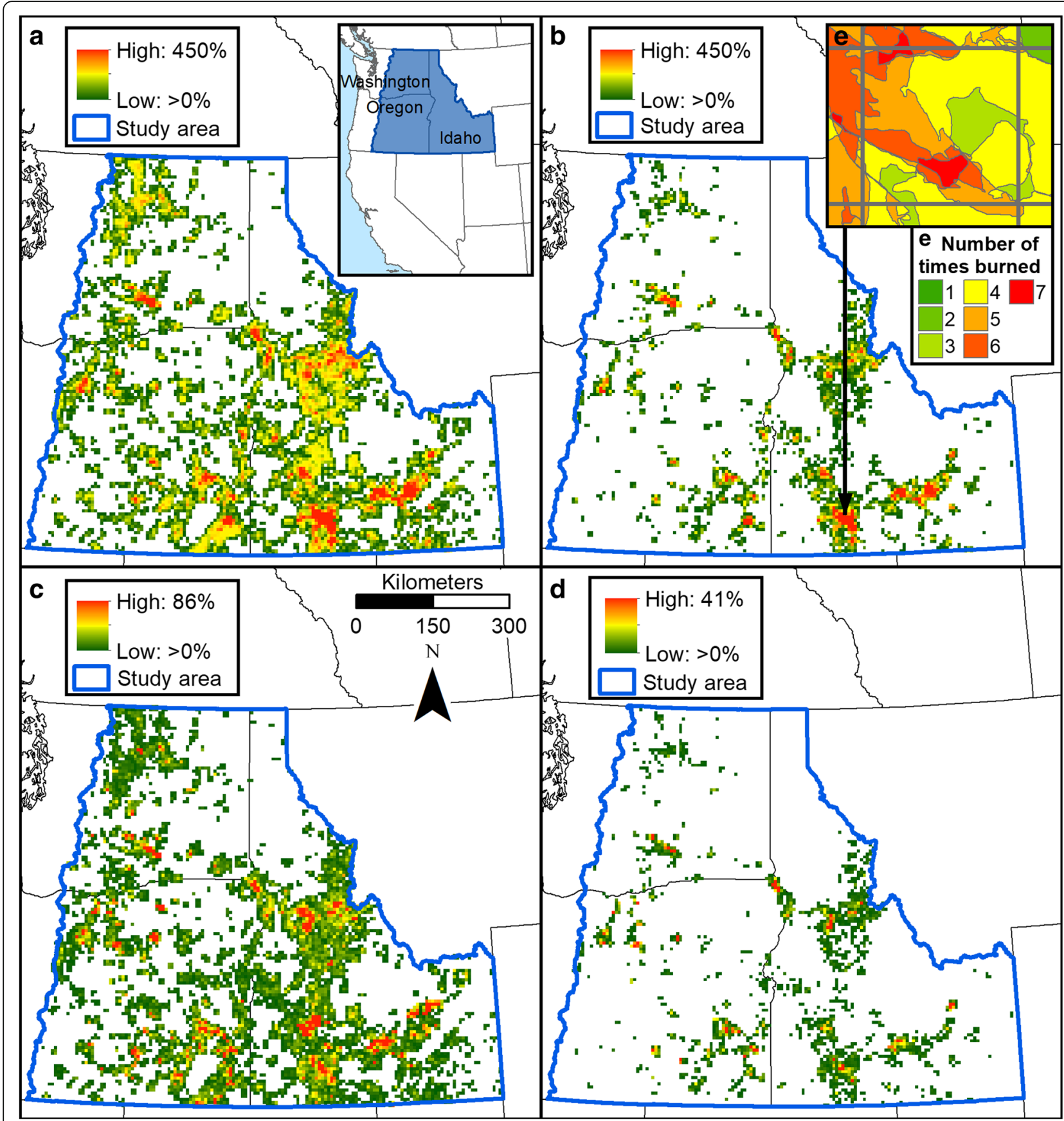

Fig. 5 Maps illustrating the proportional area of each $6 \mathrm{~km} \times 6 \mathrm{~km}$ grid cell that is covered by (a) fire perimeters within the Inland Pacific Northwest from 1984 to 2014 (including reburns, such that the proportion is cumulative and can exceed 100\% of the pixel area), (b) overlapping fire perimeters (i.e., at least two fire perimeters or reburn only), (c) all unburned islands (including persistent unburned islands), and (d) persistent unburned islands (i.e., patches that have remained unburned through at least two fires). The inset (e) illustrates the number of overlapping fire perimeters (the degree of overlap) in the most highly burned grid cell

Persistent unburned islands were more likely to be found on flatter slopes in FRGs I, III, and IV (Fig. 11; $P<$ 0.0001); however, persistent unburned islands were more likely to be found on steeper slopes in FRGs II and V $(P<$ 0.0001 and $P=0.0429$, respectively).
Persistent unburned islands were more likely to be found on more SSW aspects in FRGs I, III, IV, and V (Fig. 12; $P<0.0001$ ). The difference between the TRASP distributions for persistent unburned islands and burned areas in FRG II was insignificant $(P=0.3906)$. 

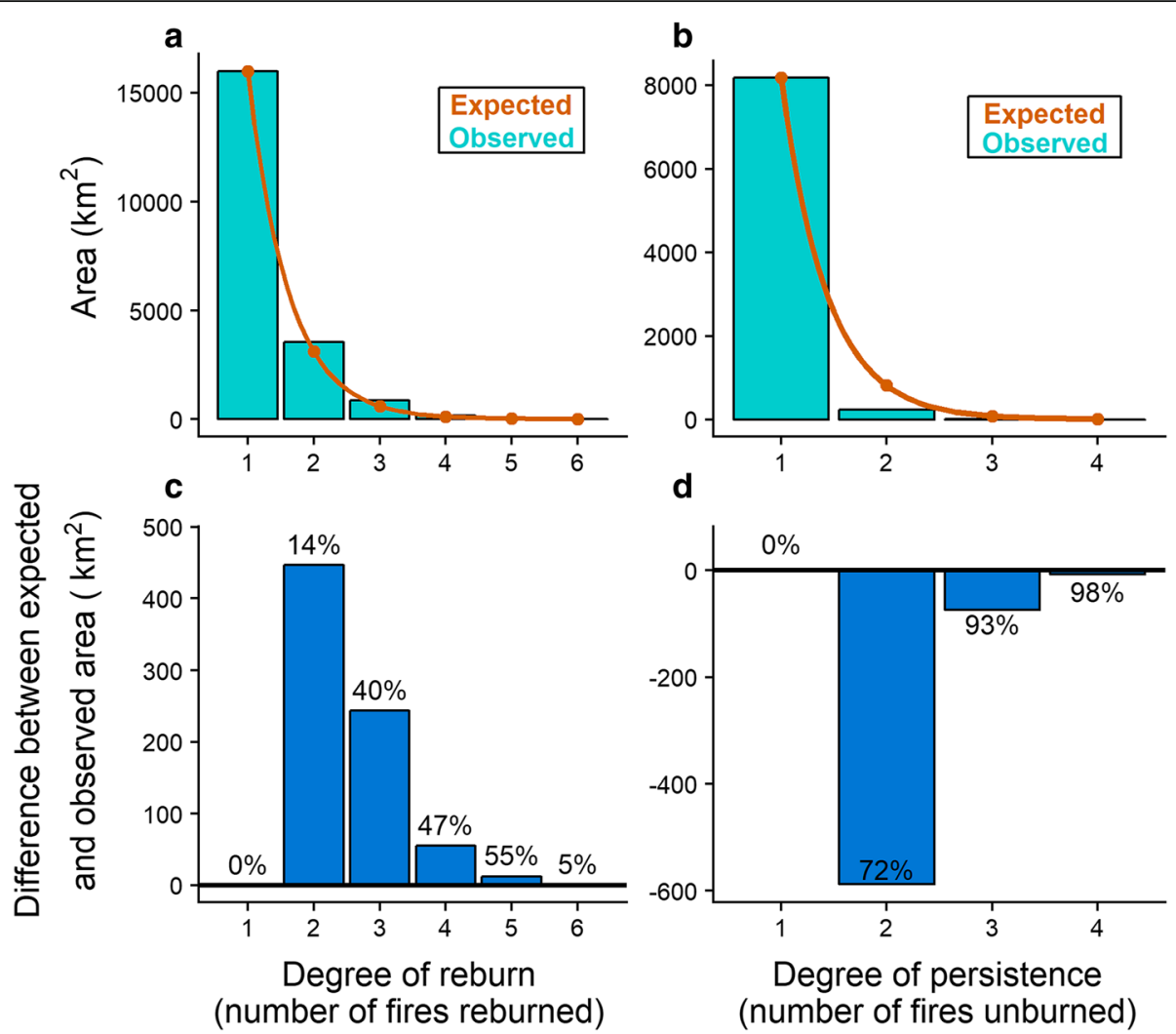

Fig. 6 (a) The observed fire perimeter area for fires within the Inland Pacific Northwest from 1984 to 2014 by degree of reburn compared to the expected fire perimeter area by degree of reburn, and (b) the observed unburned island area by the degree of persistence compared to the expected unburned island area by the degree of persistence. (c) The difference between the observed area and the expected area by the degree of reburn, and (d) the difference between the observed area and the expected area by the degree of persistence

\section{Discussion}

Our analysis revealed that there were locations that experienced up to seven overlapping fire events (i.e., reburned six times) in our 31-year study period (mean fire return interval of 4.43 years). In these frequently burned areas, primarily in southern Idaho, there were persistent unburned islands that remained unburned through up to four fires. As might be expected, persistent unburned islands decreased in number, size, and shape complexity for each additional fire it remained unburned. The dramatic decrease in the number of refugia (Fig. 3) is supported by Kolden et al. (2017), who found

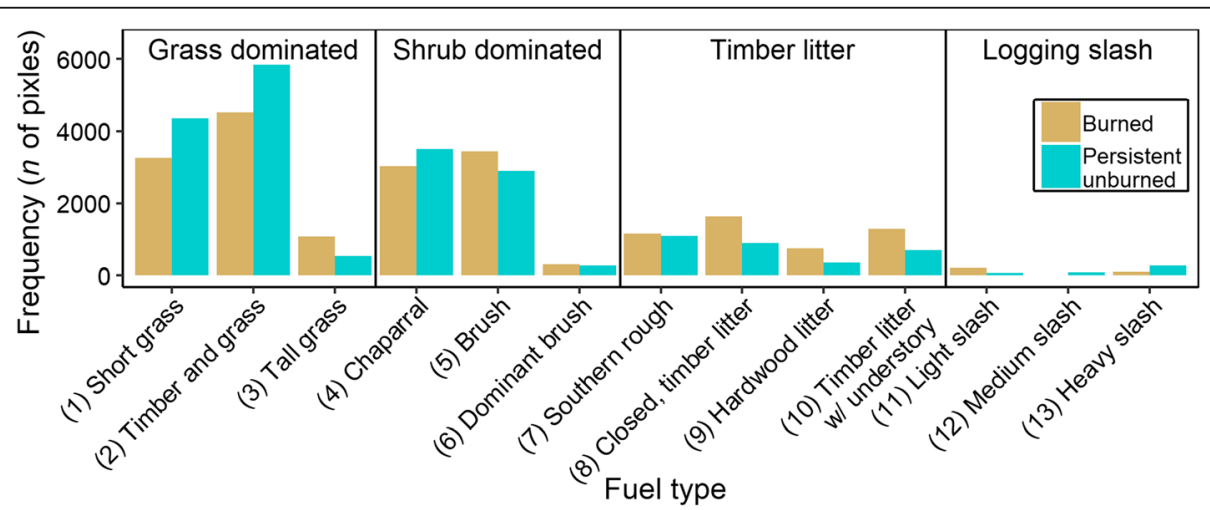

Fig. 7 Frequency of each of the Anderson fuel types for fires within the Inland Pacific Northwest from 1984 to 2014, by burn status. Note: while Fuel Type 7 (Southern rough) was initially created to describe palmetto-gallberry understory-pine overstory sites in the southern US, this group can describe other ecosystem types such as areas of tall sagebrush steppe and high montane conifer forests within our study area 
Table 4 Two-sample Kolmogorov-Smirnov $D$ statistic and $P$-values to test significance of difference between the distributions of topographic metrics among unburned islands within fires in the Inland Pacific Northwest from 1984 to 2014 based on their degree of persistence and fire regime group (FRG). The topographic metrics used for analysis were Topographical Position Index (TPI; Weiss 2001), Topographic Wetness Index (TWl; Beven and Kirkby 1979), Terrain Ruggedness Index (TRI; Riley et al. 1999), slope, the cosine of the aspect (CosAsp), and the transformed aspect (TRASP; Roberts and Cooper 1989)

\begin{tabular}{|c|c|c|c|c|c|c|c|c|c|c|c|c|c|}
\hline \multirow[t]{2}{*}{ FRG } & \multicolumn{2}{|l|}{ TPI } & \multicolumn{2}{|l|}{ TWI } & \multicolumn{2}{|l|}{ TRI } & \multicolumn{2}{|l|}{ Slope } & \multicolumn{2}{|l|}{ CosAsp } & \multicolumn{2}{|l|}{ TRASP } & \multirow{2}{*}{$\begin{array}{l}\text { Number of } \\
\text { observations }\end{array}$} \\
\hline & $D$ & $P$ & $D$ & $P$ & $D$ & $P$ & $D$ & $P$ & $D$ & $P$ & $\bar{D}$ & $P$ & \\
\hline All & 0.0425 & $<0.0001$ & 0.0689 & $<0.0001$ & 0.1108 & $<0.0001$ & 0.1030 & $<0.0001$ & 0.0483 & $<0.0001$ & 0.0492 & $<0.0001$ & $\begin{array}{l}n_{1}=30000 \\
n_{2}=30000\end{array}$ \\
\hline । & 0.1077 & $<0.0001$ & 0.1352 & $<0.0001$ & 0.1847 & $<0.0001$ & 0.1747 & $<0.0001$ & 0.0544 & $<0.0001$ & 0.0508 & $<0.0001$ & $\begin{array}{l}n_{1}=4006 \\
n_{2}=4667\end{array}$ \\
\hline$\|$ & 0.1421 & $<0.0001$ & 0.0736 & $0.1234^{*}$ & 0.2696 & $<0.0001$ & 0.2719 & $<0.0001$ & 0.0992 & $0.0126^{* *}$ & 0.0562 & $0.3906^{*}$ & $\begin{array}{l}n_{1}=939 \\
n_{2}=354\end{array}$ \\
\hline III & 0.048 & $<0.0001$ & 0.0751 & $<0.0001$ & 0.1253 & $<0.0001$ & 0.1164 & $<0.0001$ & 0.0748 & $<0.0001$ & 0.0799 & $<0.0001$ & $\begin{array}{l}n_{1}=8978 \\
n_{2}=10097\end{array}$ \\
\hline IV & 0.0412 & $<0.0001$ & 0.0726 & $<0.0001$ & 0.1118 & $<0.0001$ & 0.1016 & $<0.0001$ & 0.0475 & $<0.0001$ & 0.0305 & $<0.0001$ & $\begin{array}{l}n_{1}=15136 \\
n_{2}=13854\end{array}$ \\
\hline V & 0.0804 & 0.0035 & 0.0748 & 0.0082 & 0.058 & $0.0736^{*}$ & 0.0625 & $0.0429^{* *}$ & 0.1256 & $<0.0001$ & 0.1215 & $<0.0001$ & $\begin{array}{l}n_{1}=941 \\
n_{2}=1028\end{array}$ \\
\hline
\end{tabular}

Indicates $P>0.05$

${ }^{* *}$ Indicates $P>0.01$

that areas previously identified as fire refugia burned at higher severity and intensity 20 years later. For unburned islands that persist through multiple fires, presumably, the biophysical factors that caused them to remain unburned during a previous burn act again to allow them to remain unburned through these additional fires. However, additional fires burn the edges of a given persistent unburned island, shrinking and simplifying them, until they are completely consumed. Persistent unburned islands were not randomly distributed across the landscape. Their location was dependent not only on the existence of fires, but multiple, overlapping fire perimeters. Further, these fire locations were not randomly distributed across the landscape.

In this study, the greatest number of both overlapping fires and persistent unburned islands within those fires occurred in Idaho, but in two very different ecosystems: (1) the two central Idaho wilderness areas (Frank Church-River of No Return and Selway-Bitterroot), and (2) the Snake River Plain (Fig. 5). In the central Idaho wilderness areas, the primary ignition source is high-frequency lightning (Abatzoglou et al. 2016), and the primary vegetation is forest broken by stretches of exposed granite above tree line and talus slopes. As most of the persistent islands are concentrated along the deep Salmon River canyon, it is likely that the exposed walls and steep terrain of the canyon itself contribute to erratic fire behavior, creating persistent islands.

By contrast, the density of repeat fires and persistent unburned islands in southern Idaho is likely primarily a function of biological invasion and climatologically strong winds, in conjunction with a higher degree of human ignitions than elsewhere in the study area
(Abatzoglou et al. 2016). Across much of the Snake River Plain in Idaho and into the southeastern portion of Oregon, the annual grass cheatgrass (Bromus tectorum L.) has partially replaced the native shrub-steppe and fundamentally altered the fire regime by dramatically increasing fire frequency (Balch et al. 2013). The highest density of both fires and persistent unburned islands occurs in the Bruneau Desert, a large plateau west of Twin Falls, Idaho, that is incredibly remote and difficult to access but has a relatively high rate of human ignitions and a high density of cheatgrass (Bradley et al. 2018), facilitating large fire growth (Fig. 5e). Cheatgrass invasion into lower-elevation, relatively steep river canyons (where narrow canyon walls also support high winds) across the study is potentially responsible for several of the concentrations of persistent islands across the study area, including much of the Snake River Plain, Hells Canyon (Snake River) along the Idaho-Oregon border, the Salmon River canyon in central Idaho, the Deschutes River and John Day River canyons in central Oregon, and the Columbia River Gorge in north-central Washington. By contrast, the other cluster of persistent unburned islands in central Washington is associated with the Hanford Reach section of the Columbia River, which is a vast riparian zone (Fig. 5d).

The results of our topographic analysis are counter to what previous fire refugia research has found. While many authors have found fire refugia in valley bottoms and gullies (Romme and Knight 1981; Leonard et al. 2014; Krawchuk et al. 2016), in our study area we found that, although there was a significant relationship between topographic position and persistent unburned 


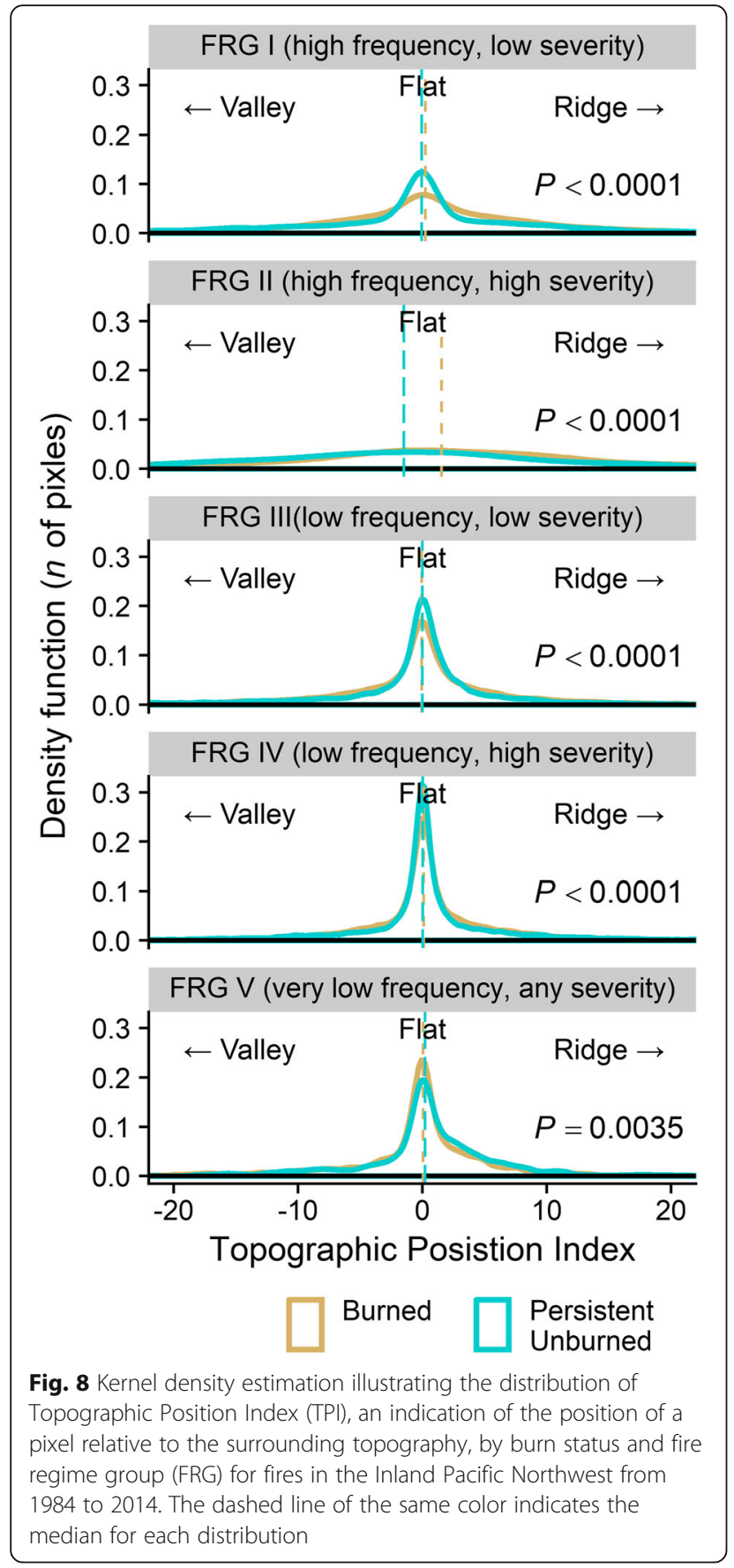

islands, the effect was small (Fig. 8). However, prior studies focused on forests, whereas our study area encompassed forests, shrublands, and arid grasslands. Likewise, forest-centric fire refugia studies have found fire refugia to be more prevalent on the cooler and wetter aspects (north and east in the Northern Hemisphere, south and east in the Southern Hemisphere; Roberts and Cooper 1989; Wood et al. 2011; Krawchuk et al. 2016). Our analysis revealed the opposite to be true in our study area for most of the FRGs, except FRG II

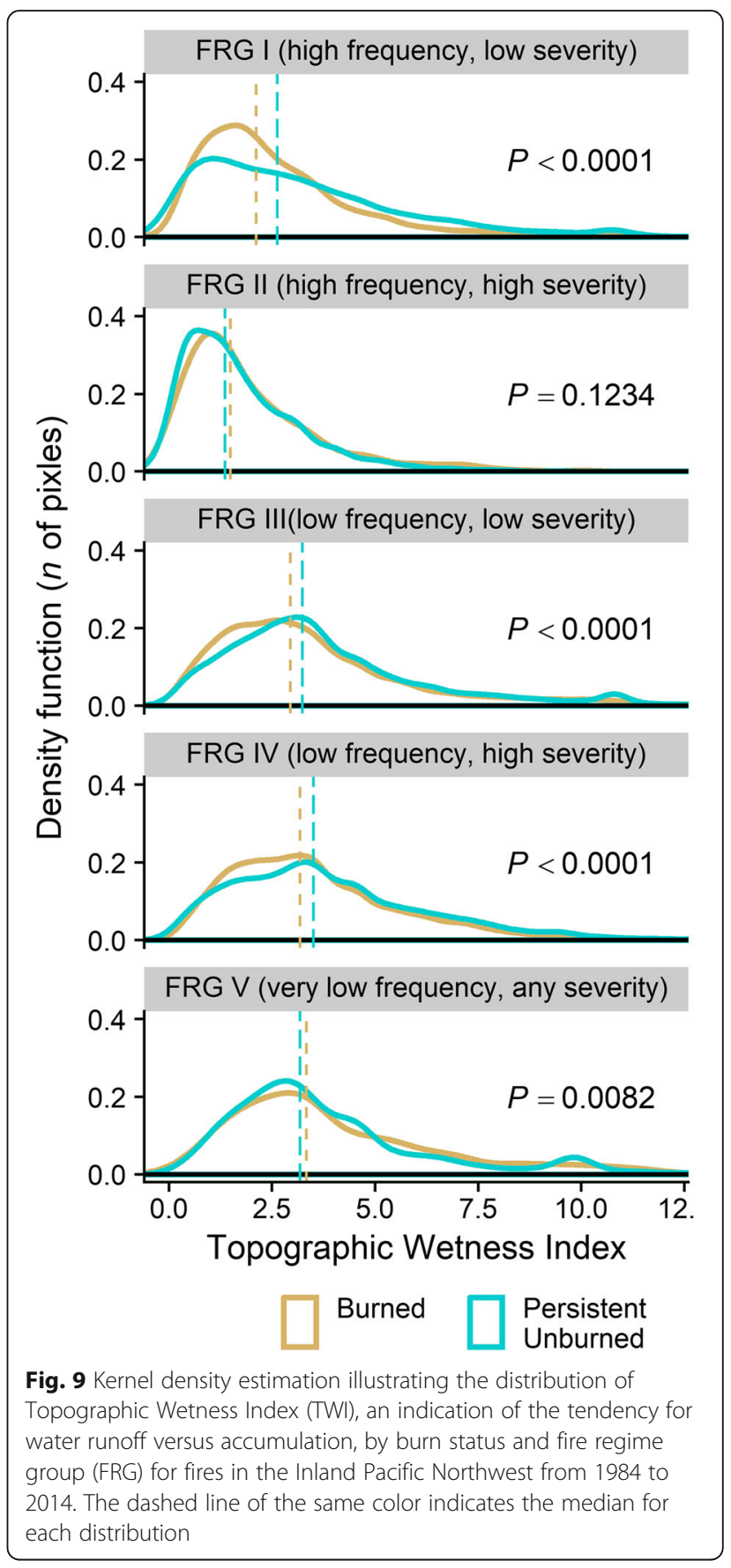

(predominantly grasslands, where there was no significant relationship; Fig. 12). We hypothesize that this is in large part due to the sparser vegetation on these warmer and drier aspects, particularly as described above in relation to canyons in the basalt-dominated Columbia Plateau, resulting in higher likelihood of unburned areas. In addition, while there is evidence that fuel types and topographic features differ in persistent unburned islands and burned areas, these features only partially explain what causes their 


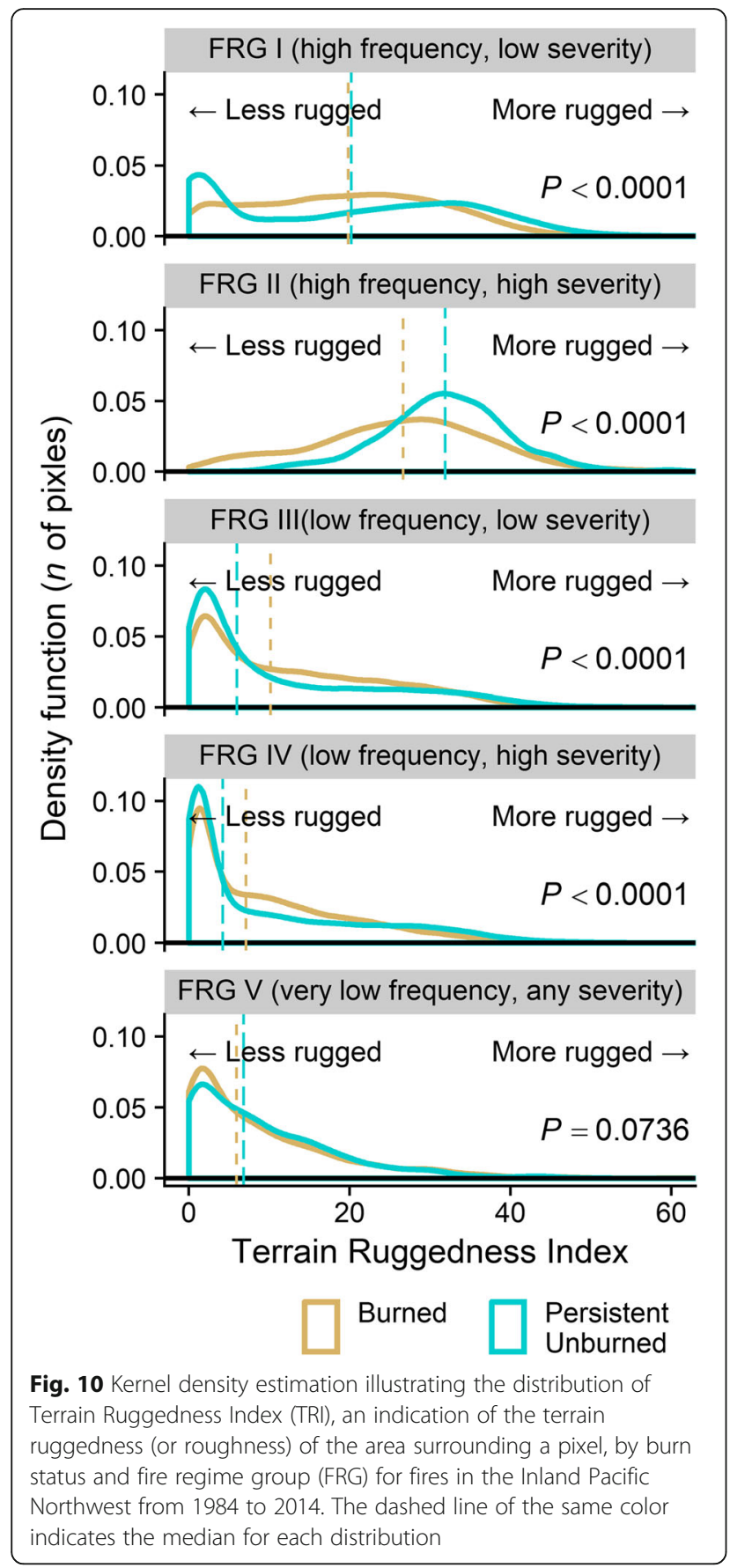

formation. Fire behavior, the ultimate determinant of the formation of unburned islands, also is driven by fire weather, not just topography and fuel type (Román-Cuesta et al. 2009).

Our results show that the forest-centric paradigm often used when investigating fire refugia is not sufficient when considering arid grasslands or shrublands. We suggest that, in the arid, non-forest ecosystems of the Inland Northwest, fire refugia are predominantly caused by fuel limitations and wind-dominated

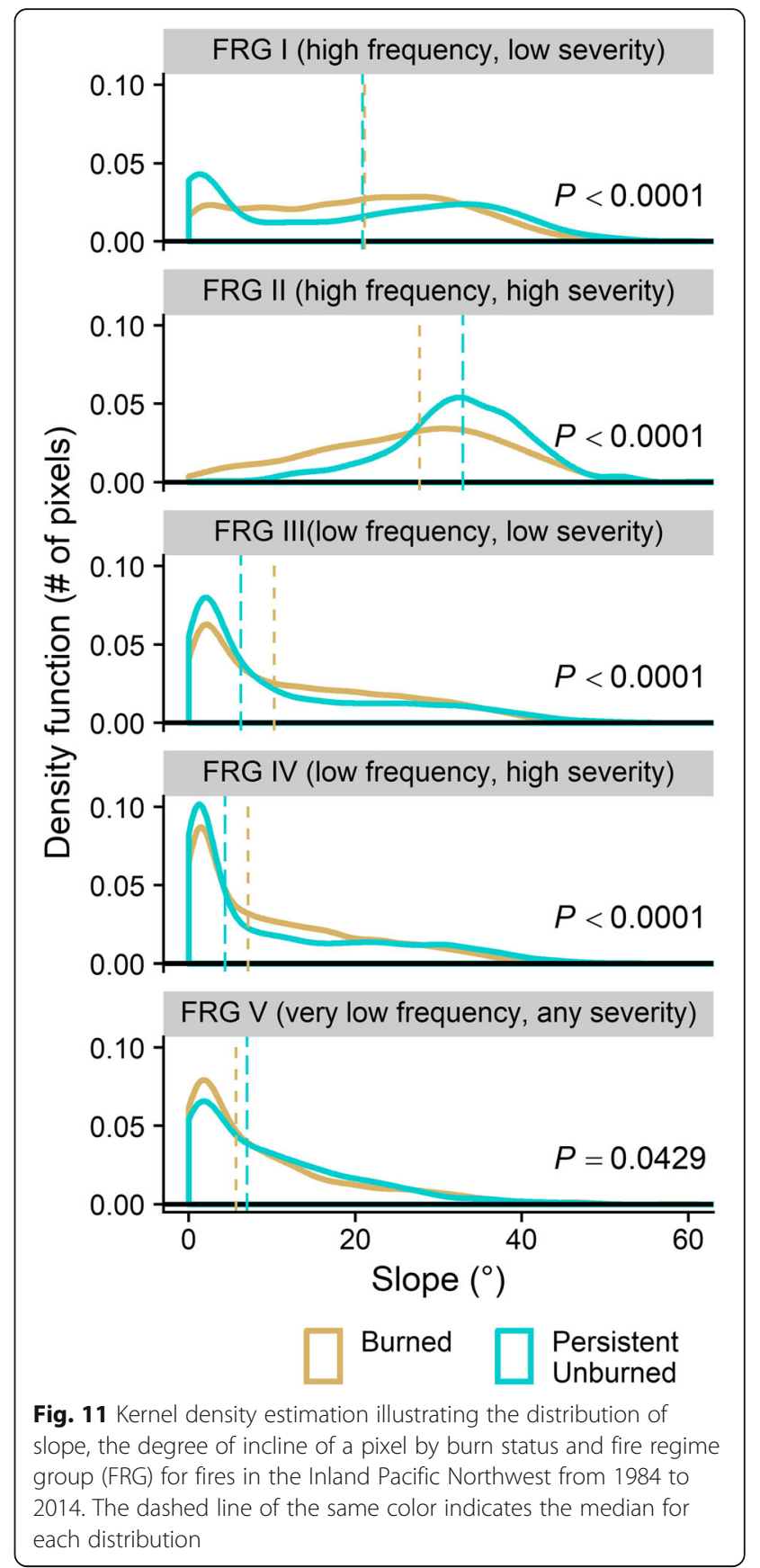

behavior, as opposed to the fire refugia described in existing literature that are found in cool, mesic forested bottoms of valleys (e.g., Camp et al. 1997). Because of the water limitation in these ecosystems, fuels are discontinuous, resulting in a patchy fire mosaic (Littell and Gwozdz 2011).

There are several key limitations of our data that affect our ability to characterize persistent unburned islands. Although there was a large number of persistent unburned islands identified across our study area, the temporal range of our dataset was limited. While our 


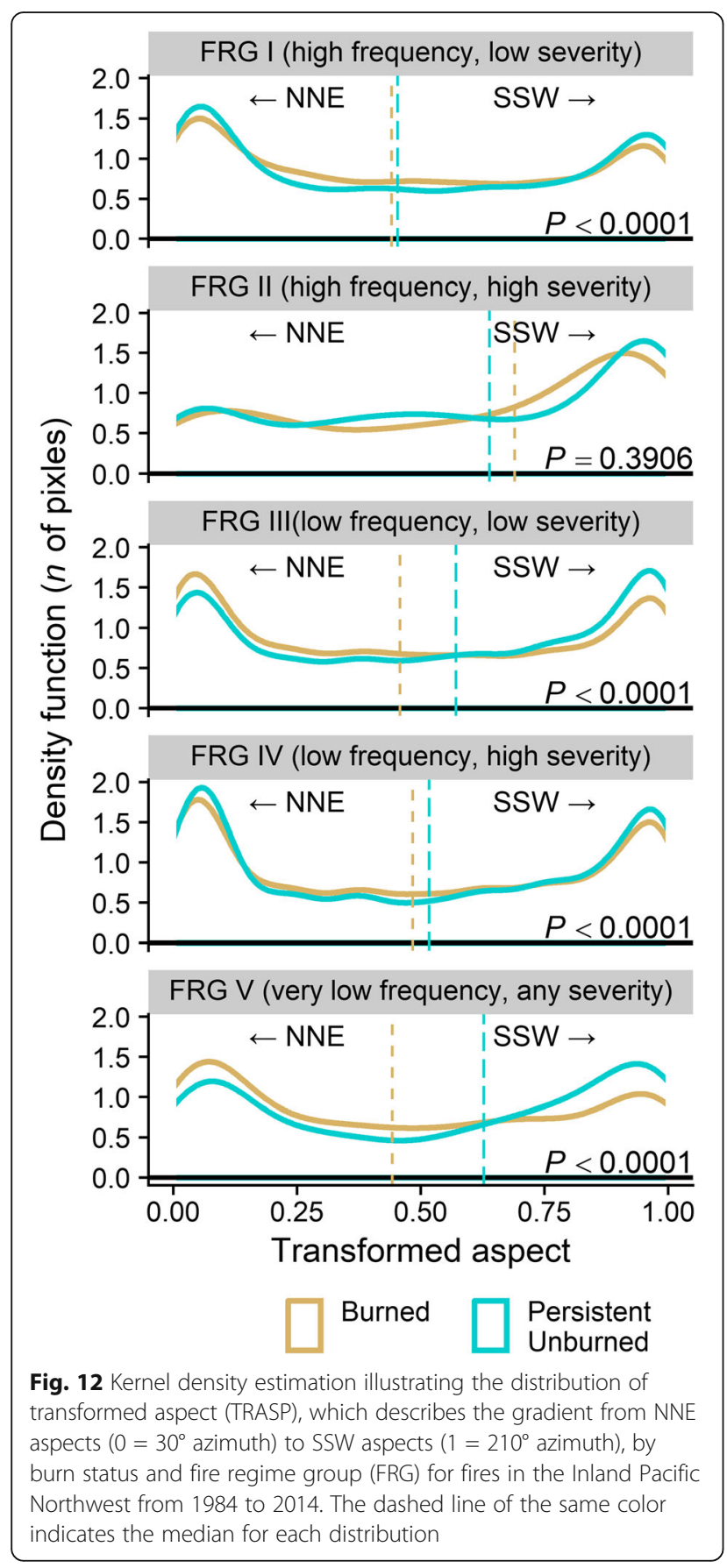

dataset covered decades, the fire return interval of many of the ecosystems in our study area was greater than 31 years, so the likelihood of experiencing more than one fire is very low. This means that many of the unburned islands identified as only persisting through a single fire event may have persisted through several more fires prior to 1984, or may persist through several more fires after 2014 (the range of our dataset). Additionally, the $30 \mathrm{~m}$ resolution of many of our datasets likely masked fine-scale variability. Fire refugia exist at a range of scales, and the resolution of our data did not capture smaller fire refugia that still may be ecologically significant (Krawchuk et al. 2016). Further, the error inherent in classifying unburned islands from remotely sensed data carries forward to analyses of persistence (Kolden et al. 2012). Finally, we note that our dataset included 100 prescribed fires that likely burned under different conditions than wildfires, including ignition patterns based on subjective decisions. However, these prescribed fires were not separated in our analysis and, therefore, differences in unburned island formation between wildfires and prescribed fires were not tested.

While unburned islands are a useful proxy for fire refugia (Robinson et al. 2013), they are not equivalent. For example, roads or rock piles may be classified as unburned islands; however, they may have little ecological value and may not function as fire refugia. Even among fire refugia, some may hold greater ecological significance than others. To address these issues, the ecological importance of unburned islands should be assessed to identify the most ecologically valuable fire refugia. This would allow for land managers and ecologists to make better informed decisions regarding the preservation of important fire refugia.

Characterizing persistent fire refugia allows us to better understand the biophysical factors that contribute to their formation. These key insights have implications for land management, especially when considering the impact of global climate change. Land managers may find that preserving and protecting fire refugia on the landscape helps them to meet their management objectives, whether by naturally revegetating the burned landscape surrounding them (Viedma et al. 1997; Charron and Greene 2002), or allowing for the persistence and recolonization of fauna after a fire event (DeLong and Kessler 2000). They also may aid in restoring and maintaining forest resilience (Kolden et al. 2015a), which may become increasingly important as our climate continues to change, fires become more extreme, and reburning occurs in shorter intervals. Land managers looking to capitalize on the benefits of fire refugia may find it beneficial to consider techniques to encourage the formation or the persistence of unburned islands on their lands. While it has been previously acknowledged that managing for refugia is an important land management principle (Lindenmayer et al. 2006), little research exists on how land managers might accomplish this; future research is needed on management techniques that may promote the formation or persistence of unburned islands (Meddens et al. 2018a).

\section{Conclusion}

Our study provides evidence that persistent unburned islands are related to certain topographic characteristics, 
but these characteristics differ between fire regime group and fuel type. These findings are important for management activities that focus on maintaining important persistent unburned islands (fire refugia) on the landscape. Fire refugia are essential to the persistence of fire sensitive taxa within fire-prone ecosystems. As the global climate continues to change and wildland fires are predicted to become larger and more frequent, fire refugia and their characteristics are expected to change with them, such that fire refugia will play an increasingly important role in the recovery and resilience of fire-prone landscapes.

\section{Additional files}

Additional file 1: Neighborhood analysis was used to calculate the Topographic Position Index (TPI; Weiss 2001) and Terrain Ruggedness Index (TRI; Riley et al. 1999) for fires in the Inland Pacific Northwest from 1984 to 2014. The seven by seven focal frame, which is $90 \mathrm{~m}$ in each direction, used third order queen contiguity, which includes all cells (orange) within the focal frame. (PDF $181 \mathrm{~kb}$ )

Additional file 2: An illustration of both aspect-derived indices used to characterize unburned islands within fires in the Inland Pacific Northwest from 1984 to 2014. The transformed aspect (TRASP; Roberts and Cooper 1989) was most informative for illustrations, although both were used in the analysis. (PDF $116 \mathrm{~kb}$ )

\section{Acknowledgements}

The views and conclusions contained in this document are those of the authors and should not be interpreted as representing the opinions or policies of the US Government. Mention of trade names or commercial products does not constitute their endorsement by the US Government. This manuscript is submitted for publication with the understanding that the United States Government is authorized to reproduce and distribute reprints for governmental purposes. Thank you S. Wozniak and J. Steenvoorden for all the helpful conversations and constant encouragement throughout the duration of this project. Thank you to D. Hammond, J. Dodge, C. BowmanPrideaux, and two anonymous reviewers who provided very helpful comments on this manuscript.

\section{Funding}

This work was partially supported by the Joint Fire Science Program (JFSP, Cooperative Agreement L16AC00202), the National Science Foundation under grant no. DMS-1520873, the University of Idaho College of Natural Resources, and the NASA Idaho Space Grant Consortium.

\section{Availability of data and materials}

The datasets generated and/or analyzed during the current study are available in the USGS ScienceBase repository, https://www.sciencebase.gov/ catalog/item/59a7452ce4bofd9b77cf6ca0

\section{Authors' contributions}

AJM, EKS, and AJHM conceived the original idea. AJM and AJHM developed the methods in consultation with EKS and ATH. AJM analyzed, summarized, and initially interpreted the data. AJM prepared all figures and took the lead writing the manuscript. AJHM, CAK, EKS, and ATH provided ecological background information and aided in the interpretation and conclusions of the results. All authors provided critical feedback and helped shape the project. All authors read and approved the manuscript.

\section{Authors' information}

Not applicable.

Ethics approval and consent to participate Not applicable.
Consent for publication

Not applicable.

\section{Competing interests}

The authors declare that they have no competing interests.

\section{Publisher's Note}

Springer Nature remains neutral with regard to jurisdictional claims in published maps and institutional affiliations.

\section{Author details}

${ }^{1}$ College of Natural Resources, University of Idaho, 975 W 6th Street, Moscow Idaho 83844, USA. ${ }^{2}$ USDA Forest Service Rocky Mountain Research Station, Forestry Sciences Laboratory, 1221 South Main Street, Moscow, Idaho 83843, USA.

Received: 21 June 2018 Accepted: 10 December 2018

Published online: 27 June 2019

\section{References}

Abatzoglou, J.T., C.A. Kolden, J.K. Balch, and B.A. Bradley. 2016. Controls on interannual variability in lightning-caused fire activity in the western US. Environmental Research Letters 11: 045005. https://doi.org/10.1088/1748-9326/ $11 / 4 / 045005$.

Abatzoglou, J.T., and A.P. Williams. 2016. Impact of anthropogenic climate change on wildfire across western US forests. Proceedings of the National Academy of Sciences of the USA 113: 11770-11775. https://doi.org/10.1073/ pnas. 1607171113

Agee, J.K. 1993. Fire ecology of Pacific Northwest forest. Washington, D.C.: Island Press.

Anderson, H.E. 1982. Aids to determining fuel models for estimating fire behavior. USDA Forest Service General Technical Report INT-122. Ogden, Utah, USDA Forest Service, Intermountain Forest Experimentation Station. https://doi.org/10. 2737/INT-GTR-122.

Bailey, R.G. 2016. Bailey's ecoregions and subregions of the United States, Puerto Rico, and the US Virgin Islands. Fort Collins, Colorado: USDA Forest Service Research Data Archive https://doi.org/10.2737/RDS-2016-0003.

Balch, J.K., B.A. Bradley, C.M. D'Antonio, and J. Gómez-Dans. 2013. Introduced annual grass increases regional fire activity across the arid western USA (1980-2009). Global Change Biology 19: 173-183. https://doi.org/10.1111/gcb.12046.

Barbero, R., J.T. Abatzoglou, N.K. Larkin, C.A. Kolden, and B. Stocks. 2015. Climate change presents increased potential for very large fires in the contiguous United States. International Journal of Wildland Fire 24: 892-899. https://doi. org/10.1071/WF15083.

Barrett, S., D. Havlina, J. Jones, W. Hann, C. Frame, D. Hamilton, K. Schon, T. Demeo, L. Hutter, and J. Menakis. 2010. Interagency fire regime condition class guidebook, version 3.0. Homepage of the interagency fire regime condition class website, USDA Forest Service, US Department of the Interior, and The Nature Conservancy. https://www.landfire.gov/frcc/frcc guidebooks. php. Accessed 10 Sept 2018.

Beven, K.J., and M.J. Kirkby. 1979. A physically based, variable contributing area model of basin hydrology. Hydrological Sciences Bulletin 24: 43-69. https://doi. org/10.1080/02626667909491834.

Bowman, D.M.S., GJ. Williamson, J.T. Abatzoglou, C.A. Kolden, M.A. Cochrane, and A.M. S. Smith. 2017. Human exposure and sensitivity to globally extreme wildfire events. Nature Ecology \& Evolution 1: 0058. https://doi.org/10.1038/541559-016-0058.

Bradley, B.A., C.A. Curtis, E.J. Fusco, J.T. Abatzoglou, J.K. Balch, S. Dadashi, and M.N. Tuanmu. 2018. Cheatgrass (Bromus tectorum) distribution in the intermountain western United States and its relationship to fire frequency, seasonality, and ignitions. Biological Invasions 20: 1493-1506. https://doi.org/ 10.1007/s10530-017-1641-8.

Breiman, L., J.H. Friedman, C.J. Stone, and R.A. Olshen. 1984. Classification and regression trees. Belmont, California: Wadsworth International Group.

Camp, A., C. Oliver, P.F. Hessburg, and R. Everett. 1997. Predicting latesuccessional fire refugia pre-dating European settlement in the Wenatchee Mountains. Forest Ecology and Management 95: 63-77. https://doi.org/10. 1016/S0378-1127(97)00006-6.

Charron, I., and D.F. Greene. 2002. Post-wildfire seedbeds and tree establishment in the southern mixedwood boreal forest. Canadian Journal of Forest Research 32: 1607-1615. https://doi.org/10.1139/×02-085.

Corder, G.W., and D.I. Foreman. 2014. Nonparametric statistics : a step-by-step approach, second edition. Hoboken, New Jersey: John Wiley \& Sons. 
De Reu, J., J. Bourgeois, M. Bats, A. Zwertvaegher, V. Gelorini, P. De Smedt, W. Chu, M. Antrop, P. De Maeyer, P. Finke, M. Van Meirvenne, J. Verniers, and P. Crombé. 2013. Application of the topographic position index to heterogeneous landscapes. Geomorphology 186: 39-49. https://doi.org/10. 1016/j.geomorph.2012.12.015.

DeLong, S.C., and W.B. Kessler. 2000. Ecological characteristics of mature forest remnants left by wildfire. Forest Ecology and Management 131: 93-106. https://doi.org/10.1016/S0378-1127(99)00203-0.

Eidenshink, J., B. Schwind, K. Brewer, Z.-L. Zhu, B. Quayle, and S. Howard. 2007. A project for Monitoring Trends in Burn Severity. Fire Ecology 3: 3-21. https:// doi.org/10.4996/fireecology.0301003.

Franklin, J.F., and C.T. Dyrness. 1973. Natural vegetation of Oregon and Washington. USDA Forest Service General Technical Report PNW-GTR-008. Portland, Oregon: USDA Forest Service, Pacific Northwest Research Station.

Gibson, C.E., P. Morgan, and A.M. Wilson. 2014. Atlas of digital polygon fire extents for Idaho and western Montana. Second edition. Fort Collins, Colorado: USDA Forest Service Research Data Archive. https://doi.org/10.2737/RDS-2009-0006-2.

Gill, L., and A.H. Taylor. 2009. Top-down and bottom-up controls on fire regimes along an elevational gradient on the east slope of the Sierra Nevada, California, USA. Fire Ecology 5: 57-75. https://doi.org/10.4996/fireecology.0503057.

Harvey, B.J., D.C. Donato, and M.G. Turner. 2016. Burn me twice, shame on who? Interactions between successive forest fires across a temperate mountain region. Ecology 97: 2272-2282. https://doi.org/10.1002/ecy.1439.

Higuera, P.E., J.T. Abatzoglou, J.S. Littell, and P. Morgan. 2015. The changing strength and nature of fire-climate relationships in the northern Rocky Mountains, USA, 1902-2008. PLoS One 10: 1-21. https://doi.org/10.1371/ journal.pone.0127563.

Hollander, M., E. Chicken, and D.A. Wolfe. 2014. Nonparametric statistical methods, third edition. Hoboken, New Jersey: John Wiley \& Sons.

Hudak, A.T., N.L. Crookston, J.S. Evans, D.E. Hall, and M.J. Falkowski. 2008. Nearest neighbor imputation of species-level, plot-scale forest structure attributes from LiDAR data. Remote Sensing of Environment 112: 2232-2245. https://doi. org/10.1016/j.rse.2007.10.009.

Kolden, C., and J. Abatzoglou. 2018. Spatial distribution of wildfires ignited under katabatic versus non-katabatic winds in mediterranean southern California USA. Fire 1: 19. https://doi.org/10.3390/fire1020019.

Kolden, C.A., J.T. Abatzoglou, J.A. Lutz, C.A. Cansler, J.T. Kane, J.W. van Wagtendonk, and C.H. Key. 2015a. Climate contributors to forest mosaics: ecological persistence following wildfire. Northwest Science 89: 219-238. https://doi.org/10.3955/046.089.0305.

Kolden, C.A., T.M. Bleeker, A.M.S. Smith, H.M. Poulos, and A.E. Camp. 2017. Fire effects on historical wildfire refugia in contemporary wildfires. Forests $8: 1-16$ https://doi.org/10.3390/f8100400.

Kolden, C.A., J.A. Lutz, C.H. Key, J.T. Kane, and J.W. van Wagtendonk. 2012. Mapped versus actual burned area within wildfire perimeters: characterizing the unburned. Forest Ecology and Management 286: 38-47. https://doi.org/10 1016/j.foreco.2012.08.020

Kolden, C.A., A.M.S. Smith, and J.T. Abatzoglou. 2015b. Limitations and utilisation of Monitoring Trends in Burn Severity products for assessing wildfire severity in the USA. International Journal of Wildland Fire 24: 1023-1028. https://doi. org/10.1071/WF15082.

Kolden, C.A., and P.J. Weisberg. 2007. Assessing accuracy of manually-mapped wildfire perimeters in topographically dissected areas. Fire Ecology 3: 22-31. https://doi.org/10.4996/fireecology.0301022.

Krawchuk, M.A., S.L. Haire, J. Coop, M.-A. Parisien, E. Whitman, G. Chong, and C. Miller. 2016. Topographic and fire weather controls of fire refugia in forested ecosystems of northwestern North America. Ecosphere 7: e01632. https://doi. org/10.1002/ecs2.1632.

LANDFIRE. 2011 a. Fire Regime Groups (LANDFIRE 1.0.5). https://www.landfire.gov/ frg.php. Accessed 10 Sept 2018

LANDFIRE. 2011b. 13 Anderson fire behavior fuel models (LANDFIRE 1.0.5). https://www.landfire.gov/fbfm13.php. Accessed 10 Sept 2018.

Leonard, S.W.J., A.F. Bennett, and M.F. Clarke. 2014. Determinants of the occurrence of unburnt forest patches: potential biotic refuges within a large, intense wildfire in south-eastern Australia. Forest Ecology and Management 314: 85-93. https://doi.org/10.1016/j.foreco.2013.11.036.

Lindenmayer, D.B., J.F. Franklin, and J. Fischer. 2006. General management principles and a checklist of strategies to guide forest biodiversity conservation. Biological Conservation 131: 433-445. https://doi.org/10.1016/j. biocon.2006.02.019.
Littell, J.S., and R.B. Gwozdz. 2011. Climatic water balance and regional fire years in the Pacific Northwest, USA: linking regional climate and fire at landscape scales. In The landscape ecology of fire. Edited by D. McKenzie, C. Miller, and D.A. Falk. Pages 117 139. New York: Springer. https://doi.org/10.1007/978-94-007-0301-8_5.

Littell, J.S., D. McKenzie, D.L. Peterson, and A.L. Westerling. 2009. Climate and wildfire area burned in western US ecoprovinces, 1916-2003. Ecological Applications 19: 1003-1021. https://doi.org/10.1890/07-1183.1.

Malesky, D.M., B.J. Bentz, G.R. Brown, A.R. Brunelle, J.M. Buffington, L.M. Chappell, R.J. DeRose, J.C. Guyon II, C.L. Jorgensen, R.A. Loehman, L.L. Lowrey, A.M. Lynch, M. Matyjasik, J.D. McMillin, J.E. Mercado, J.L. Morris, J.F. Negron, W.G. Padgett, R.A. Progar, and C.B. Randall. 2018. Effects of climate change on ecological disturbances. Chapter 8. In Climate change vulnerability and adaptation in the Intermountain Region. Part 2. USDA Forest Service General Technical Report RMRS-GTR-375. Edited by J.E. Halofsky, D.L. Peterson, J.J. Ho, N.J. Little, and L.A. Joyce. Pages 199-263. Fort Collins, Colorado, YSA: USDA Forest Service, Rocky Mountain Research Station.

McGarigal, K., and B.J. Marks. 1995. FRAGSTATS: spatial pattern analysis program for quantifying landscape structure. USDA Forest Service General Technical Report PNW-GTR-351. Portland, Oregon: USDA Forest Service, Pacific Northwest Research Station. https://doi.org/10.2737/PNW-GTR-351.

McKenzie, N.J., and P.J. Ryan. 1999. Spatial prediction of soil properties using environmental correlation. Geoderma 89: 67-94. https://doi.org/10.1016/ S0016-7061(98)00137-2.

Meddens, A.J.H., C.A. Kolden, and J.A. Lutz. 2016. Detecting unburned areas within wildfire perimeters using Landsat and ancillary data across the northwestern United States. Remote Sensing of the Environment 186: 275-285. https://doi.org/10.1016/j.rse.2016.08.023.

Meddens, A.J.H., C.A. Kolden, J.A. Lutz, J.T. Abatzoglou, and A.T. Hudak. 2018a. Spatiotemporal patterns of unburned areas within fire perimeters in the northwestern United States from 1984 to 2014. Ecosphere 9: e02029. https:// doi.org/10.1002/ecs2.2029.

Meddens, A.J.H., C.A. Kolden, J.A. Lutz, A.M.S. Smith, C.A. Cansler, J.T. Abatzoglou, G.W. Meigs, W.M. Downing, and M.A. Krawchuk. 2018b. Fire refugia: what are they, and why do they matter for global change? Bioscience 68 (12): 944-954. https://doi.org/10.1093/biosci/biy103.

Moisen, G.G., and T.S. Frescino. 2002. Comparing five modelling techniques for predicting forest characteristics. Ecological Modelling 157: 209-225. https:// doi.org/10.1016/S0304-3800(02)00197-7.

Morgan, P., E.K. Heyerdahl, and C.E. Gibson. 2008. Multi-season climate synchronized forest fires throughout the 20th century, northern Rockies, USA. Ecology 89: 717-728. https://doi.org/10.1890/06-2049.1.

Morgan, P., A.T. Hudak, A. Wells, S.A. Parks, L.S. Baggett, B.C. Bright, and P. Green. 2017. Multidecadal trends in area burned with high severity in the SelwayBitterroot Wilderness Area 1880-2012. International Journal of Wildland Fire 26 (11): 930-943. https://doi.org/10.1071/WF17023.

Prichard, S.., C.S. Stevens-Rumann, and P.F. Hessburg. 2017. Tamm review: shifting global fire regimes: lessons from reburns and research needs. Forest Ecology and Management 396: 217-233. https://doi.org/10.1016/j.foreco.2017.03.035.

Riley, S.., S.D. DeGloria, and R. Elliot. 1999. A terrain ruggedness index that quantifies topographic heterogeneity. Intermountain Journal of Sciences 5: 23-27.

Roberts, D.W., and S.V. Cooper. 1989. Concepts and techniques in vegetation mapping. In Proceedings - land classification based on vegetation: applications for resource management. USDA Forest Service General Technical Report INT-GTR-257. Edited by D. Ferguson, F.D. Johnson, and P. Morgan. Pages 90-96. Ogden, Utah: USDA Forest Service, Intermountain Research Station.

Robinson, N.M., S.W.J. Leonard, E.G. Ritchie, M. Bassett, E.K. Chia, S. Buckingham, H. Gibb, A.F. Bennett, and M.F. Clarke. 2013. REVIEW: refuges for fauna in fireprone landscapes: their ecological function and importance. Journal of Applied Ecology 50: 1321-1329. https://doi.org/10.1111/1365-2664.12153.

Rollins, M.G., T.W. Swetnam, and P. Morgan. 2001. Evaluating a century of fire patterns in two Rocky Mountain wilderness areas using digital fire atlases. Canadian Journal of Forest Research 31: 2107-2123. https://doi.org/10.1139/ x01-141.

Román-Cuesta, R.M., M. Gracia, and J. Retana. 2009. Factors influencing the formation of unburned forest islands within the perimeter of a large forest fire. Forest Ecology and Management 258: 71-80. https://doi.org/10.1016/j. foreco.2009.03.041.

Romme, W.H., and D.H. Knight. 1981. Fire frequency and subalpine forest succession along a topographic gradient in Wyoming. Ecology 62: 319-326. https://doi.org/10.2307/1936706. 
Scott, J.H., and R.E. Burgan. 2005. Standard fire behavior fuel models: a comprehensive set for use with Rothermel's surface fire spread model. USDA Forest Service General Technical Report RMRS-GTR-153. Fort CollinsColorado, USA: USDA Forest Service, Rocky Mountain Research Station. https://doi.org/ 10.2737/RMRS-GTR-153.

Shynk, J.J. 2012. Probability, random variables, and random processes : theory and signal processing applications. Hoboken, New Jersey: John Wiley \& Sons.

Smith, A.M.S., C.A. Kolden, T.B. Paveglio, M.A. Cochrane, D.M.J.S. Bowman, M.A. Moritz, A.D. Kliskey, L. Alessa, A.T. Hudak, C.M. Hoffman, J.A. Lutz, L.P. Queen, S.J. Goetz, P.E. Higuera, L. Boschetti, M. Flannigan, K.M. Yedinak, A.C. Watts, E. K. Strand, J.W. van Wagtendonk, J.W. Anderson, B.J. Stocks, and J.T. Abatzoglou. 2016a. The science of firescapes: achieving fire-resilient communities. BioScience 66: 130-146. https://doi.org/10.1093/biosci/biv182.

Smith, A.M.S., A.M. Sparks, C.A. Kolden, J.T. Abatzoglou, A.F. Talhelm, D.M. Johnson, L. Boschetti, J.A. Lutz, K.G. Apostol, K.M. Yedinak, W.T. Tinkham, and R. Kremens. 2016b. Towards a new paradigm in fire severity research using dose-response experiments. International Journal of Wildland Fire 25: 158166. https://doi.org/10.1071/WF15130.

Stevens-Rumann, C., and P. Morgan. 2016. Repeated wildfires alter forest recovery of mixed-conifer ecosystems. Ecological Applications 26: 1842-1853. https:// doi.org/10.1890/15-1521.1.

Stevens-Rumann, C., S. Prichard, and E. Strand. 2016. Prior wildfires influence burn severity of subsequent large fires. Canadian Journal of Forest Research 46 : 1375-1385. https://doi.org/10.1139/cjfr-2016-0185.

Stevens-Rumann, C.S., K.B. Kemp, P.E. Higuera, B.J. Harvey, M.T. Rother, D.C. Donato, P. Morgan, and T.T. Veblen. 2018. Evidence for declining forest resilience to wildfires under climate change. Ecology Letters 21: 243-252. https://doi.org/10.1111/ele.12889.

US Geological Survey. 2011. Gap Analysis Program. National land cover, version 2. https://www.usgs.gov/core-science-systems/science-analytics-and-synthesis/ gap. Accessed 27 Aug 2018

US Geological Survey. 2016. USGS National Elevation Dataset (NED) 1 arc-second downloadable data collection from The National Map 3D Elevation Program (3DEP) - National Geospatial Data Asset (NGDA) National Elevation Data set (NED). https://www.sciencebase.gov/catalog/item/ 5825a0c3e4b01fad86db66dc Accessed 18 June 2018.

Vaillant, N.M., C.A. Kolden, and A.M.S. Smith. 2016. Assessing landscape vulnerability to wildfire in the USA. Current Forestry Reports 2: 201-213. https://doi.org/10.1007/s40725-016-0040-1.

van Wagtendonk, J.W., K.A. van Wagtendonk, and A.E. Thode. 2012. Factors associated with the severity of intersecting fires in Yosemite National Park, California, USA. Fire Ecology 8 (1): 11-31. https://doi.org/10.4996/fireecology. 0801011.

Viedma, O., J. Meliá, D. Segarra, and J. García-Haro. 1997. Modeling rates of ecosystem recovery after fires by using Landsat TM data. Remote Sensing of Environment 61: 383-398. https://doi.org/10.1016/S0034-4257(97)00048-5.

Weiss, A.D. 2001. Topographic positions and landforms analysis (conference poster). ESRI international user conference, 9-13 July 2001, San Diego, California, USA. Redlands, California: ESRI.

Westerling, A.L. 2016. Increasing western US forest wildfire activity: sensitivity to changes in the timing of spring. Philosophical Transactions of the Royal Society B: Biological Sciences 371: 20150178. https://doi.org/10.1098/rstb.2015.0178.

Wood, S.W., B.P. Murphy, and D.M.J.S. Bowman. 2011. Firescape ecology: how topography determines the contrasting distribution of fire and rain forest in the south-west of the Tasmanian Wilderness World Heritage Area. Journal of Biogeography 38: 1807-1820. https://doi.org/10.1111/j.1365-2699.2011.02524.x.

\section{Submit your manuscript to a SpringerOpen ${ }^{\circ}$ journal and benefit from:}

- Convenient online submission

- Rigorous peer review

- Open access: articles freely available online

- High visibility within the field

- Retaining the copyright to your article

Submit your next manuscript at $\boldsymbol{\nabla}$ springeropen.com 